\title{
To Have and to Hold: What Does Love (of Money) Have to Do WITH JoINT TAX FILING?
}

\author{
Stephanie Hunter McMahon*
}

\begin{abstract}
Wealthy taxpayers have always attempted to reduce their federal income taxes. Before 1948, when the United States had an individual-based system, one popular method was to shift income between spouses so that more of a husband's income could be reported by and taxed to his lower-income, and thus lower-tax-bracket, wife. Congress eliminated the reward for this tax-avoidance behavior in 1948 by nationalizing income splitting via the joint return. Today, there are proposals to return to an individual-based system. Evaluating the proposal for individual filing, this Article first explores the development of the income-splitting joint return as a historical guide to the potential costs of this proposal. The Article then rejects the prospect that today's Internal Revenue Service (IRS) will be able to rein in a resurgence of this type of tax avoidance. Finally, in addition to these practical concerns, this Article contends that calculations on a unitary basis remain today, as in the past, more accurate and more just for judging a married couple's ability to pay taxes when compared to other taxpayers. As a result of these considerations, the joint return is the more equitable method of marital tax filing.
\end{abstract}

\section{INTRODUCTION}

Nothing may be certain except for death and taxes, but people try to cheat both. Before 1948, one way married couples sought to cheat the latter was to shift the ownership of income between spouses, for tax purposes at least, so that more income could be taxed at the tax rates applicable to the lower-income spouse. As tax rates rose during World War II, one commentator recognized that "[o]ne of the results of higher tax rates has been a burst of generosity on the part of prosperous husbands." ${ }^{1}$ More troublesome for the integrity of the tax system was that "the intimate relationship of husband and wife sometimes enable the consummation of transactions perfect in form, but wholly lacking in substance." 2 Traditionally, this meant that husbands would transfer ownership

* I would like to thank Leandra Lederman, Ajay Mehrotra, Diane Ring, Jim Maule, Leslie Book, Dennis Ventry, and Chris Bryant, as well as participants of the 2009 Critical Tax Conference, the 2009 Law and Society Conference, and the faculty of Villanova University Law School for their helpful comments on previous drafts of this Article and the Harold C. Schott Foundation for financial support.

1 Robert M. Yoder, She's Dear, but Is She Deductible? Saturday Evening Post, Oct. 12, 1946, at $17,141$.

2 Randolph E. Paul \& Valentine B. Havens, Husband and Wife Under the Income Tax, 5 BRoOK. L. Rev. 241, 255 (1936). 
of some portion of their income-producing assets to their wives while retaining control over those assets and the income produced; wives would then report, and pay tax on, the income without having the benefits of ownership. In an attempt to remove the economic incentive for income shifting, Congress nationalized income splitting for married couples filing joint tax returns. ${ }^{3}$ Today, legal scholars are proposing the return to a system of individual filing in which these legalisms will again be useful. ${ }^{4}$

Recent attacks on joint taxation are not unexpected; the joint return has faced numerous attacks over the years. By requiring spouses to combine their income for calculating the taxes due, joint taxation can push more income into higher tax brackets, producing a larger collective tax burden than would be due if the spouses had not married. ${ }^{5}$ On the other hand, the tax brackets used for the joint return are wider than for individual filers so that some couples, those with a primary earner, have lower collective taxes than they would if that primary earner had been taxed as a single individual. Politicians understand these conflicting effects, rhetorically labeling the economic advantage and disadvantage resulting from joint filing as a "marriage bonus" and a "marriage penalty."

Recent history illustrates how individual filing's economic consequences can produce strange bedfellows of socially conservative family groups and liberal academics. ${ }^{6}$ After President Bill Clinton restored higher marginal tax rates, and hence larger marriage bonuses and penalties, it was socially conservative Republicans, as part of the Contract with America, who urged marriage penalty relief. ${ }^{7}$ A Republican-controlled Congress also sought legislation that would have allowed optional separate filing and, in turn, allowed couples to choose the filing method that would optimally reduce their collective taxes. ${ }^{8}$ Republicans fought this battle again in 2001 and secured limited marriage penalty relief, accelerated in 2003, by flattening tax rates and doubling the size of

3 Revenue Act of 1948, Pub. L. No. 80-471, §§ 301-303, 62 Stat. 110, 114-16 (1948). Pursuant to nationalized income splitting, a couple filing jointly would only owe federal income tax equal to twice the amount that would have been due on half its income. If one spouse earned most or all of the couple's income, that spouse's income was effectively taxed in tax brackets that were twice as wide as they would be if that spouse filed as a single taxpayer. The method of calculating joint tax obligations has since been changed to a separate bracket schedule. I.R.C. $\S 1$ (2006). For a more thorough discussion of Congress's motives, see infra pp. 735-737. In this Article, joint filing and joint taxation are used interchangeably, unless otherwise indicated, as most advocates argue for both individual filing and individual taxation.

4 See infra notes 10,12 , and 14.

5 This is the result of a 1969 legislative change intended to ease the burden on single taxpayers. Tax Reform Act of 1969, Pub. L. No. 91-172, § 803, 83 Stat. 487, 192-96 (1969). Since 1969, the brackets of married couples have been less than twice those of single individuals. See, e.g., id. at 195-96. Spouses can file separately but with less favorable tax brackets than with joint filing.

6 Compare, e.g., Allan C. Carlson, Taxing the Family: An American Version of Paradise Lost, in Fractured Generations: Crafting a Family Policy for Twenty-First CenTURY AMERICA 89, 89 (2005), with the list of scholars infra notes 10, 12, and 14.

7 American Dream Restoration Act, H.R. 6, 104th Cong. (1995) (fulfilled promise from Republican leaders outlining their plan if they were to take the House majority during the 1994 Congressional election).

8 See, e.g., Marriage Tax Elimination Act, H.R. 2456, 105th Cong. (1997) (if passed this resolution would have amended the I.R.C. of 1986). 
the lower tax brackets. ${ }^{9}$ The result also increased marriage bonuses for many couples with a primary income earner. As this legislation is set to expire in 2012, renewed pressure to maintain the marriage-bonus tax reduction is to be expected.

Alternatively, liberal academics who urge the return to individual filing focus not on tax cuts but on three consequences of the joint return. First, many argue that the joint return is a means to discriminate against families' secondary earners. ${ }^{10}$ They complain that because wives are more often the lower-earning spouses, the value of their wages is discounted within the family because wives are psychologically taxed at their husbands' highest tax rate. ${ }^{11}$ Second, many

9 Jobs and Growth Tax Relief Reconciliation Act of 2003, Pub. L. No. 108-27, §§ 102-103, 117 Stat. 752, 754 (2003); Economic Growth and Tax Relief Reconciliation Act of 2001, Pub. L. No. 107-16, $\S 301-302,115$ Stat. 38, 53-54 (2001). These changes only reduced taxes for those with taxable incomes more than $\$ 47,450$. Press Release, Office of Pub. Affairs, Tax Provisions of the Jobs and Growth Tax Relief Reconciliation Act of 2003 (May 22, 2003), available at http//www.ustreas.gov/press/releases/js408.htm.

${ }^{10}$ For a discussion of the secondary earner bias, see infra pp. 750-751. Among the dozens of authors commenting on this topic, see Alice Kessler-Harris, In Pursuit of Equity 170-202 (2001); Edward J. McCaffery, Taxing Women 19-20 (1997); Alicia H. MunNELL, The Couple Versus the Individual Under the Federal Personal Income Tax, in THE Economics of Taxation 247 (Henry J. Aaron \& Michael J. Boskin eds., 1980); Boris I. Bittker, Federal Income Taxation and the Family, 27 Stan. L. Rev. 1389, 1394-95 (1975); Grace Blumberg, Sexism in the Code: A Comparative Study of Income Taxation of Working Wives and Mothers, 21 Buff. L. Rev. $49-98$ (1972); Amy C. Christian, The Joint Return Rate Structure: Identifying and Addressing the Gendered Nature of the Tax Law, 13 J.L. \& Pol. 241, 242 (1997); Pamela B. Gann, Abandoning Marital Status as a Factor in Allocating Income Tax Burdens, 59 Tex. L. Rev. 1, 4 (1980); Wendy C. Gerzog, The Marriage Penalty: The Working Couple's Dilemma, 47 Fordham L. Rev. 27, 32-33 (1978); Anthony C. Infanti, Decentralizing Family: An Inclusive Proposal for Individual Tax Filing in the United States, 2010 Utah L. Rev. (forthcoming 2011); Carolyn C. Jones, Split Income and Separate Spheres: Tax Law and Gender Roles in the 1940s, 6 LAw \& Hist. Rev. 259, 260 (1988); Marjorie E. Kornhauser, Love, Money, and the IRS: Family, Income-Sharing, and the Joint Income Tax Return, 45 Hastings L.J. 63, 64 (1993); Michael J. McIntyre \& Oliver Oldman, Taxation of the Family in a Comprehensive and Simplified Income Tax, 90 HARv. L. Rev. 1573, 1573-74 (1977); Shari Motro, A New "I Do": Towards a Marriage-Neutral Income Tax, 91 Iowa L. Rev. 1509, 1512 (2006); Bea Ann Smith, The Partnership Theory of Marriage: A Borrowed Solution Fails, 68 Tex. L. Rev. 689, 692 (1990); Lawrence Zelenak, Marriage and the Income Tax, 67 S. CAL. L. Rev. 339, 339-40 (1994); Lora Cicconi, Comment, Competing Goals Amidst the "Opt-Out" Revolution: An Examination of Gender Based Tax Reform in Light of New Data on Female Labor Supply, 42 Gonz. L. Rev. 257, 258-60 (2006-2007); Wendy Richards, Comment, An Analysis of Recent Tax Reforms from a Marital-Bias Perspective: It Is Time to Oust Marriage from the Tax Code, 2008 WIs. L. Rev. 611, 614 (2008); James Edward Maule, Tax and Marriage: Unhitching the Horse and the Carriage, TAx Notes, Apr. 24, 1995, at 539, 548; see also Anne L. Alstott, Tax Policy and Feminism: Competing Goals and Institutional Choices, 96 Colum. L. Rev. 2001, 2013 (1996) (noting the conflict between giving spouses equal treatment, encouraging women to work, and assisting caregivers, each as separate feminist goals); Lily Kahng, One Is the Loneliest Number: The Single Taxpayer in a Joint Return World, 61 Hastings L.J. 651, 653 (2010) (argues against the joint return on the ground that it disadvantages single taxpayers). An alternative might be joint filing for unearned income and individual filing for earned income; however, not only would this impose administrative costs on taxpayers, it also would put pressure on the definition of earned income.

11 See generally sources cited supra note 10. The author is a wife who works despite these perceived economic disincentives. 
of these scholars oppose the joint and several liability currently imposed on filers of joint returns. ${ }^{12}$ They question whether both spouses should be liable for tax on the income a joint return reports, or fails to report, because of the lopsided power structure within many families. ${ }^{13}$ Finally, scholars have condemned the discrimination against same-sex couples who, even if their unions are recognized under state law, remain unable to file joint tax returns. However, this treatment is subject to change as a result of recent court rulings. ${ }^{14}$ These critics urge either the abolition of the joint return or the expansion of the right to file joint returns to same-sex couples registered under state law, so they receive tax treatment similar to that of opposite-sex couples. ${ }^{15}$

Although each of these issues needs to be considered when evaluating the equity of our modern tax system, this Article urges the addition of tax avoidance as an integral part of any analysis of the appropriate tax unit. The history of the federal income tax prior to 1948, when we had an individual-based system, is full of wealthy taxpayers, and legislators acting on their behalf, adopting a wide variety of tactics to avoid taxes. As discussed below, these methods ranged from individual gifts to wholesale revisions of state property laws. Many of these tactics succeeded and allowed private individuals and state legislators to directly reduce federal income tax receipts from the wealthiest American couples, threatening the equitable foundation of the tax. Those studying how the tax unit currently operates discount these unintended consequences of individual filing, but these consequences are still possible because there remains something unique about the married couple that warrants unique tax treatment. That unique something about marriage that makes tax avoidance

12 See, e.g., Richard C.E. Beck, The Failure of Innocent Spouse Reform, 51 N.Y.L. SCH. L. Rev. 928, 930 (2006-2007); Richard C.E. Beck, The Innocent Spouse Problem: Joint and Several Liability for Income Taxes Should Be Repealed, 43 VAND. L. Rev. 317, 319 (1990); Amy C. Christian, Joint and Several Liability and the Joint Return: Its Implications for Women, 66 U. Cin. L. Rev. 535, 536 (1998); Lily Kahng, Innocent Spouses: A Critique of the New Tax Laws Governing Joint and Several Tax Liablity, 49 Vill. L. Rev. 261, 262 (2004); Adrianne Hodgkins, Comment, Getting a Second Chance: The Need for Tax Court Jurisdiction Over IRS Denials of Relief Under Section 66, 65 LA. L. REv. 1167, 1167 (2005); M. Meghan Kerns, Note, Duress: A Perplexing Barrier to Relief from Joint and Several Liability, 58 Hastings L.J. 1123, 1123-24 (2007).

13 See generally sources cited supra note 12.

14 Compare Defense of Marriage Act of 1996, Pub. L. No. 104-199, 110 Stat. 2419 (1996), with Gill v. Office of Pers. Mgmt., 699 F. Supp. 2d 374, 387 (D. Mass. 2010) (The U.S. District Court of Massachusetts struck the Defense of Marriage Act as it applied to the litigants). With an extension of its ruling, same-sex couples married under state law could file joint returns and not be allowed to file as single individuals. For scholarship on this issue, see generally Patricia A. Cain, Federal Tax Consequences of Civil Unions, 30 CAP. U. L. Rev. 387, 387 (2002); Patricia A. Cain, Taxing Families Fairly, 48 Santa Clara L. Rev. 805, 805 (2008); William P. Kratzke, The Defense of Marriage Act (DOMA) Is Bad Income Tax Policy, 35 U. Mem. L. Rev. 399, 401 (2005); Theodore P. Seto, The Unintended Tax Advantages of Gay Marriage, 65 WAsh. \& LeE L. Rev. 1529, 1572 (2008); Keeva Terry, Separate and Still Unequal? Taxing California Registered Domestic Partners, 39 U. Tol. L. Rev. 633, 634-35 (2008); Dennis J. Ventry, Jr., Saving Seaborn: Ownership Not Marriage as the Basis of Family Taxation, 86 IND. L.J. (forthcoming 2011). I agree that joint filing should be extended to registering same-sex couples, see infra p. 756.

15 See generally sources cited supra note 14. 
more likely also makes the couple the best measure of the collective's ability to pay taxes.

This Article's argument proceeds in three parts. Part II begins by describing the forces that led to nationalized income splitting via the joint return in 1948. Correcting the current historical record, it evaluates the tax-avoidance behavior, and failed attempts to prevent it, that necessitated a national solution. However, just because tax avoidance brought about the adoption of the couple as the tax unit does not necessarily mean that we should retain this regime sixty years later. Certainly, times and families have changed. Therefore, Part III looks at practical reasons why we should retain the joint return, namely the need to minimize today's tax avoidance. Not only are married couples more likely than single taxpayers to understate their income, the IRS's current administrative (in)capacity warns that it would be unable to stop a recurrence of widespread tax avoidance. ${ }^{16}$ Part IV then examines individual filing against the principle that the tax system should raise revenue from taxpayers based on their ability to pay taxes. Regardless of whether one defines ability to pay in terms of a taxpayer's control over income or the benefit a taxpayer receives from income, how the government measures an individual's ability to pay should be made in comparison to other taxpayers, especially where the issue, as with the tax unit, involves relative tax burdens. ${ }^{17}$

The Article concludes by explaining why an alternative conception of the tax-unit issue, balancing relative tax burdens politically, will never produce a satisfying result. As with many political issues, the choice of a tax unit is essentially a zero-sum game. Any choice will cause primary-earner couples, two-earner couples, or single taxpayers to benefit relative to the others through the shifting of tax burdens. In other words, there were, and remain, relative economic losers for each choice. To find the best long-term solution to this issue, we need to examine and weigh any change's potential consequences, both for better and for worse, as well as its impact on the theoretical underpinnings of the system.

To be clear, this Article only examines the appropriate tax-filing unit. It does not make claims regarding the relative tax burdens of single versus married taxpayers, which could be addressed by changes in tax rate brackets, or the method of assigning tax liability between spouses filing joint returns. These questions are beyond the scope of this Article because they only become necessary when, and if, we accept joint filing as the best tax unit.

16 See James Andreoni, Brian Erard \& Jonathan Feinstein, Tax Compliance, 36 J. Econ. Literature 818, 818 (1998); Steve Johnson, The 1998 Act and the Resources Link Between Tax Compliance and Tax Simplification, 51 U. Kan. L. Rev. 1013, 1013 (2003); Leandra Lederman, Tax Compliance and the Reformed IRS, 51 U. Kan. L. Rev. 971, 982 (2003); Eric A. Posner, Law and Social Norms: The Case of Tax Compliance, 86 VA. L. Rev. 1781, 1782-84 (2000); David A. Weisbach, Ten Truths About Tax Shelters, 55 TAx L. Rev. 215, 215 (2002). The 1988 Taxpayer Compliance Measurement Program revealed that joint filers understate taxes by an average of $\$ 428$ compared with $\$ 179$ for taxpayers in other categories. Andreoni, Erard \& Feinstein, supra at 822 n.15.

17 There are, of course, other theories supporting progressive income taxation. For the sake of length, this Article only discusses the ability to pay taxes. The same arguments regarding the tax unit would apply under other theories supporting progressive taxation, such as the utility theory or the benefit theory. 


\section{History's GUIDANCE}

When the federal income tax was enacted in 1913 there was little consideration of the appropriate tax unit. Although policymakers were aware that wealthy couples had used the family as a means of tax avoidance under the Civil War income tax, how to prevent this tax avoidance as well as the relative tax treatments of husbands and wives and their single counterparts went unanalyzed when the tax was reintroduced. ${ }^{18}$ Congressman Cordell Hull contemplated requiring spouses to file jointly, but he ultimately concluded that married women's property acts would make such a law unconstitutional because joint taxation effectively ignores the separate interests the property acts created. ${ }^{19}$ Hull's concern put an end to this suggestion and any further discussion of these issues. As a result, in 1913, Congress adopted a system that defaulted to treating the individual as the basic unit for measuring the amount of federal income taxes owed when it taxed the "net income of every individual." 20 That language remained largely unchanged until the enactment of the Revenue Act of 1948.

After the tax's enactment in October 1913, the Treasury Department had less than a month to prepare regulations governing its practical operation, so the Department had to make important decisions quickly. ${ }^{21}$ At the time, married women's participation in the paid labor force was declining and husbands' wages were the sole source of income for the vast majority of American families. ${ }^{22}$ In this environment, the Treasury Department took the position that the 1913 income tax, despite its language, taxed married couples as units: "The husband, as the head and legal representative of the household and general custodian of its income, should make and render the return of the aggregate income of himself and wife." ${ }^{23}$ The Department understood that such treatment would impose a penalty on some marriages. One example it used was where each spouse had a separate income of less than the $\$ 3,000$ individual exemption but together their combined incomes exceeded the $\$ 4,000$ married

18 See, e.g., Cong. Globe, 38th Cong., 1st Sess. 2515-16 (1864) (remarks of Senator Henry Wilson (R-MA)). The concern during the Civil War was income shifting to take advantage of high exemptions. Id.

19 Robert H. Montgomery, Federal Tax Handbook Supplement 1941-42, § 1016 (1941). Hull likely meant to have husbands file their families' returns, as they did in Wisconsin. See Hoeper v. Tax Comm'n, 284 U.S. 206, 215 (1931), discussed infra pp. 730-731. This proposal was not widely debated. 50 Cong. ReC. 1254-56, 3771, 3850-51 (1913).

20 Tariff of 1913, Pub. L. No. 63-16, § 2, 38 Stat. 114, 166 (1913). There was more debate regarding exemptions. See id.

21 Treasury Dep't, Annual Report of the Secretary of the Treasury on the State of the Finances, H.R. Doc. No. 63-358, at 5 (1913).

22 Government reports indicate that married women's participation fell from 10.7 percent in 1910 to 9 percent in 1920, but rebounded to 11.7 percent in 1930. Bureau of the Census, U.S. Dep't of Commerce, Historical Statistics of the United States: Colonial Times to 1970, at 133 ser. D 49-62 (1975). Although these numbers likely undercount the percentage of working wives, the number of wives who would have received taxable income was low, and it is only this subset that would impact the tax-filing question.

23 T.D. 1923, 15 Treas. Dec. Int. Rev. 298 (1913). Throughout the statute, Congress taxes either the "individual" or the "person." T.D. 1882, 15 Treas. Dec. Int. Rev. 203 (1913). This raises a question of statutory interpretation as to whether the Treasury Department had the authority to issue this regulation. 
exemption. ${ }^{24}$ Under the Department's interpretation, this couple had to pay taxes even though neither would have owed tax if they were not married. ${ }^{25}$

The Treasury Department's imposition of joint taxation was similar to the expectation of family unity held by most Americans of the period. The era's labor debate, for example, presupposed this sort of cohesive family unit, with labor organizers seeking to secure for each (presumably male) worker a wage, the so-called "family wage," that was adequate to meet his family's needs. ${ }^{26}$ This presumption of unity extended in practice to federal taxation. When, in 1914, married women were first allowed to file separately, fewer than seven thousand filed separately from their husbands. ${ }^{27}$

Nevertheless, many in the government were uncertain whether the Treasury Department's initial determination of the taxable unit was correct. The Treasury Department, in fact, changed its position the following year, requiring husbands and wives to file separately. ${ }^{28}$ Partly in response, in 1916 Ways and Means Committee Chairman Claude Kitchin proposed

[t]hat the aggregate net income of all members of any family, composed of one or both parents and one or more minor children, or of husband and wife living together, shall . . . constitute one taxable income to be returned by, and taxed to, the husband or the head of said family, and the tax thereon shall be payable by such husband, or head of the family ... 29

After Kitchin's proposal failed to gain traction, the Attorney General offered a new approach allowing state law to determine who owned what income regardless of how couples filed their tax returns. ${ }^{30}$ The next year the Solicitor of Internal Revenue clarified this executive interpretation: for the calculation of a couple's tax obligation, if - and only if - a couple chose to file a joint return, the couple would be treated as a unit and "the income disclosed by the return [would be] subject to both normal and surtax as though the return were that of a single individual." ${ }^{31}$ The Solicitor opined that spouses, by choosing to file a joint return, were effectively overriding state ownership tests. Because few

24 T.D. 1923, 15 Treas. Dec. Int. Rev. 298 (1913).

25 See id.

26 See Martha May, Bread Before Roses: American Workingmen, Labor Unions and the Family Wage, in Women, Work and Protest: A Century of US Women's Labor HisTORY 1, 2 (Ruth Milkman ed., 1985); Maurine Weiner Greenwald, Working-Class Feminism and the Family Wage Ideal: The Seattle Debate on Married Women's Right to Work, 19141920, 76 J. Aм. Hist. 118, 121 (1989). This is not to suggest there was not significant feminist opposition to the family wage. See Dorothy Sue Cobble, The Other Women's Movement: Workplace Justice and Social Rights in Modern America 116-20 (2004). 27 In 1914, these seven thousand returns were a little more than 2 percent of the total number of returns filed by married taxpayers, and they included those of wives who did not live with their husbands and so were legally unable to file jointly. AnNual Report of the Secretary of the Treasury on the State of the Finances, H.R. Doc. No. 63-1521, at 32 n.1 (1915). Of course, economic concerns were not the only motivation for filing joint returns.

28 This applied only to the surtax. T.D. 2090, 16 Treas. Dec. Int. Rev. 259 (1914); T.D. 2137, 17 Treas. Dec. Int. Rev. 48 (1915).

2953 Cong. Rec. 10,663, 10,664 (1916) (H.R. 16763, § 7(a) was read aloud at Chairman's request). See also 56 Cong. REc. 10,419-22, 11,312 (1918).

30 Income Tax-Community Property, 32 Op. Att'y Gen. 298 (1920).

31 Sol. Op. 90, 4 C.B. 236, 238 (1921); see also O.D. 960, 4 C.B. 255 (1921); I.T. 1997, 3-1 C.B. 149 (1924). 
couples had income in higher tax brackets, and thus no income-shifting opportunities, this imposed little cost.

After this rapid exchange of views, it was clear that the appropriate tax unit was a policy issue with no easy answer. The House of Representatives legislated in 1921 that couples had an option to file joint returns; if couples chose the unitary approach, it had attendant obligations, namely that the tax due would be computed on aggregate income. ${ }^{32}$ Congress ignored issues of how property should be allocated between spouses' returns if they did not file jointly and of spouses' relative liability if they did file together.

As these rules were being developed, few people actually paid any federal income tax. In 1913, less than 2 percent of the labor force paid income taxes. ${ }^{33}$ In 1918, at the height of financing World War I, 15 percent of the population paid income tax, but the wealthiest 1 percent paid 80 percent of the revenue raised. ${ }^{34}$ The small group of wealthy taxpayers shouldering this burden sought to reduce their federal taxes, in part by shifting income to lower-income, and hence lower-taxed, spouses. For many heads of families, the goal was to shift income for federal tax purposes without transferring control over the income or at least over the underlying property. The Treasury Department worked to allow only "legitimate" transactions to shift income between spouses but, because the federal tax deferred many questions of ownership to state law, the government struggled to decipher which of these devices had substance.

The easiest means for couples to shift income between spouses was for one spouse either to sell or to make a gift of income-producing property to the lower-income spouse. ${ }^{35}$ If income-producing property was owned by a spouse who had no other income, the income it produced would be taxed in the lowest brackets. Soon after the inception of the income tax, for example, Morton $\mathrm{H}$. Meinhard, owner of a one-half interest in the lease of the Bristol Building in New York City, assigned to his wife his interest in the lease and the profits that it generated. ${ }^{36}$ In Meinhard v. Salmon, in litigation over the renewal of the lease, then-New York Court of Appeals Judge Benjamin Cardozo confidently asserted:

The purpose of the assignment, understood by every one concerned, was to lower the plaintiff's tax by taking income out of his return and adding it to the return to be made by his wife. She was the appointee of the profits, to whom checks were to be remitted. Beyond that, the relation was to be the same as it had been. ${ }^{37}$

32 Revenue Act of 1921, Pub. L. No. 67-98, § 223(b)(2), 42 Stat. 227, 250 (1921); H.R. ReP. No. 67-350, at 13 (1921).

33 W. Elliot Brownlee, Historical Perspective on U.S. Tax Policy Toward the Rich, in DoES Atlas Shrug? The Economic Consequences of Taxing the Rich 29, 41 (Joel B. Slemrod ed., 2000); W. Elliott Brownlee, Federal Taxation in America: A Short History 56-57 (2d ed. 2004).

34 Brownlee, Federal Taxation, supra note 33, at 63.

35 The gift tax was not introduced until 1924, so spouses could transfer appreciated property without triggering a tax. See infra note 49 . Couples could also separately report the income from joint tenancies and tenancies by the entirety, provided this was consistent with the rights afforded by state and local law. See Roswell Magill, Taxable Income 274 (1936).

36 Meinhard v. Salmon, 164 N.E. 545, 549 (N.Y. 1928). Meinhard's wife re-conveyed the property to her husband before the lease renewal. In re Meinhard, 3 B.T.A. 612, 612 (1926).

37 Meinhard, 164 N.E. at 549. 
Disdainful of this purpose, the future Supreme Court Justice disregarded the transfer for purposes of the dispute over the lease, refusing to allow a taxplanning device to affect state business practices. ${ }^{38}$ Notwithstanding the transparency of Meinhard's action, the Board of Tax Appeals accepted the transfer without comment. ${ }^{39}$

The only means available to the Treasury Department to police the legitimacy of these transactions was through the requirement that the arrangements be bona fide, a test that required time-consuming oversight by the IRS. ${ }^{40}$ To satisfy this requirement, the donor must lose control: ${ }^{41}$ a husband could wake up someday and realize that he had lost control of a valuable asset to a newly empowered wife. To avoid the loss of control, many husbands decided to establish trusts holding investment property that, with careful planning, could minimize lost control and yet obtain the desired tax savings. ${ }^{42}$ This made trusts very popular. Early in the Great Depression, Secretary of the Treasury Department Henry Morgenthau, Jr., complained that one Baltimore resident established sixty-four trusts for his wife and three children, thereby saving more than $\$ 485,000$ in federal income taxes in one year. ${ }^{43}$

Another popular device was the partnership, although this only worked for families that operated an ongoing business. James W. Cannon, one of richest men in North Carolina, and whose son-in-law worked for the Treasury Department, used a family partnership to avoid hundreds of thousands of dollars in federal income tax. ${ }^{44}$ Nevertheless, partnerships were also at risk of having their favorable tax treatment denied on the ground that they were not bona fide. The Treasury Department performed a case-by-case analysis of their often murky facts and circumstances. Consequently, cases involving these arrangements tended to rely very precisely on their particular facts. ${ }^{45}$ This created great uncertainty in the application of the income tax and denied equal tax treatment to similarly situated taxpayers. Ultimately, family partnerships were found valid in only 35 percent of the cases brought to test their income-shifting

38 Id.

39 At issue was the wife's depreciation deduction. In re Meinhard, 3 B.T.A. at 614 . To be fair, the taxpayer and Commissioner stipulated that Morton conveyed his interest to his wife by absolute gift. Id.

40 See, for example, infra note 46 regarding the rise of litigation over family partnerships. The Bureau of Internal Revenue (BIR) officially changed its name to the Internal Revenue Service (IRS) in 1953. For simplicity, I will refer to the BIR as the IRS throughout this Article.

41 Edson v. Lucas, 40 F.2d 398, 404 (8th Cir. 1930), rev'g 11 B.T.A. 621 (1928).

42 Philip M. Stern, The Great Treasury Raid 77-80 (1964).

43 John Morton Blum, From the Morgenthau Diaries: Years of Crisis, 1928-1938, at 330 (1959).

${ }^{44}$ Blair as Tax Chief Blocked in Senate, N.Y. Times, May 4, 1921, at 3; see also Blair Confirmation Deferred in Senate, N.Y. Times, May 8, 1921, at 21; Johnson Loses Fight on Blair Nomination, N.Y. Times, May 18, 1921, at 2.

45 Compare, e.g., Knapp v. Comm'r, 5 B.T.A. 762 (1926), with Kelley v. Comm'r, 9 B.T.A. 832 (1927). 
ability. ${ }^{46}$ Despite this risk, couples took aggressive positions with partnerships in the hopes of securing lower taxes. ${ }^{47}$

Despite their prevalence, these techniques to avoid tax liability had drawbacks. For one, they required the loss of control to some degree by the income's original owner, even though this might mean little in the context of a marriage. Even worse for taxpayers was that, by 1930, it was clear that none of these devices were effective for shifting wage income. ${ }^{48}$ Furthermore, depending upon when couples employed these devices, they could trigger the immediate obligation of federal gift taxes. ${ }^{49}$ Finally, there was no assurance when couples adopted a particular device that the IRS would recognize it as effectively shifting income. Couples could use a device for a number of years before the government would determine whether it was effective. If a couple failed to convince the government of the validity of its actions, the couple could be liable not only for back taxes but also for penalties and interest covering the entire period it employed the device. ${ }^{50}$

A potentially more effective device to shift income between spouses was state community property law. ${ }^{51}$ Because this justification for income shifting was based on laws that were uniformly applicable to the citizens of their states, community property income shifting avoided the fact-specific examinations and related uncertainty that common law devices entailed. In point of fact, however, community property systems differed from the common law more in form than in substance, not least because many of the community property states' lawyers had been trained in eastern states and brought a distinctly common law approach to drafting and, perhaps more importantly, interpreting the

46 Jones, supra note 10 , at 278 . The 49 percent record for all partnerships also seems low. The success rate for trusts was about 50 percent. See infra text accompanying note 68 . Stern concluded that between 1939 and 1948, the number of partnership tax returns more than tripled and, in 1947, nearly one-third of partnerships included the wife or child of one of the partners. See STERn, supra note 42, at 73.

47 See, e.g., Mitchell v. Bowers, 9 F.2d 414, 414-15 (S.D.N.Y. 1925); Rossmoore v. Comm'r, 76 F.2d 520, 520-21 (2d Cir. 1935); Rossmoore v. Anderson, 67 F.2d 1009, 1009 (2d Cir. 1933) (per curiam). But see G.C.M. 3421, 7-1 C.B. 106, 106 (1928).

48 This is true at least in common law states. See infra discussion p. 729 of Lucas v. Earl, 281 U.S. 111 (1930).

49 Revenue Act of 1924, Pub. L. No. 68-176, § 319, 43 Stat. 253, 313 (1924). The gift tax was repealed by the Revenue Act of 1926, Pub. L. No. 69-20, § 1200(a), 44 Stat. 9, 125-26 (1926), and re-enacted in 1932 to prevent avoidance of the estate tax. See Revenue Revision, 1932: Hearings Before the H. Comm. on Ways \& Means, 72d Cong. 429 (1932). For a discussion of the re-enactment, see The Revenue Act of 1932, 32 Colum. L. Rev. 1205, 1205-24 (1932).

50 See I.R.C. $\$ \S 6601-6751$ for interest and penalties provisions.

51 For a discussion, see Jones, supra note 10, at 278; Stephanie Hunter McMahon, To Save State Residents: States' Use of Community Property for Federal Tax Reduction, 1939-1947, 27 Law \& Hist. Rev. 585 (2009); Jennifer E. Sturiale, The Passage of Community Property Laws, 1939-1947: Was "More than Money" Involved?, 11 Мich. J. Gender \& L. 213 (2005); see also T.D. 2450, 19 Treas. Dec. Int. Rev. 38 (1917); Income Tax-Community Property, 32 Op. Att'y Gen. 298 (1920); O.D. 426, 2 C.B. 198 (1920); T.D. 3568, 3-1 C.B. 84 (1924); Community Property in California-Estate Tax, 34 Op. Att'y Gen. 395 (1924). The Treasury Department's Regulations issued in 1921 denied California favorable tax treatment. T.D. 3295, 24 Treas. Dec. Int. Rev. 220 (1922). 
community property provisions. ${ }^{52}$ Because of what was soon perceived as geographical discrimination, some officials in the federal government wanted to eliminate community property's tax advantages. In the 1920s, the Treasury Department led two charges against the community property advantage but failed. ${ }^{53}$

It was in the community property context that the Supreme Court was first asked to rule on income shifting between spouses, and the Court took a tough stand on this form of tax avoidance. In United States v. Robbins, the question was whether all of a couple's community income could be assessed to the husband. ${ }^{54}$ Writing for all but Justice George Sutherland, Justice Oliver Wendell Holmes, Jr., denied California couples favorable federal income tax treatment based on the fact that California wives were deemed by their own state supreme court to have a mere expectancy, and not a vested right, in their one-half interest of community property. ${ }^{55}$ Holmes went further, arguing that, even assuming California wives' interests were vested, Congress could still tax husbands on the whole of the family's income. ${ }^{56}$

As the Supreme Court began to take action, frustration over the lack of tax uniformity resulting from common law and community property income shifting began to spread beyond the Treasury Department and the Court. Edwin R. A. Seligman, a pioneer of American public finance, complained to Congress that the community property advantage, lost to California after Robbins but still available in the other community property states, was creating significant financial injustice. ${ }^{57}$ Seligman wanted Congress to legislate a national solution: "Perhaps it would not be worth while [from a revenue perspective], but as a matter of equal justice I think it should be done." ${ }^{58}$ Stanley S. Surrey, future Assistant Secretary of Tax Policy, protested, "Attempts of taxpayers to spread their income and thus avoid surtax brackets, while retaining some control over the income or the property from which it is derived, has led in recent years to

52 Even lawyers in community property states disagreed over the degree of ownership a wife had. See, e.g., Harriet S. Daggett, The Modern Problem of the Nature of the Wife's Interest in Community Property-A Comparative Study, 19 CAL. L. Rev. 567 (1931); William Q. de Funiak, A Review in Brief of Principles of Community Property, 32 Ky. L.J. 63, 63-74 (1943); Roswell Magill, The Federal Income Tax on the Family, 20 TEx. L. Rev. 150 (1941); J. Emmett Sebree, Federal Taxation of Community Property, 12 TEx. L. Rev. 273 (1933). The leading scholar of community property noted in 1925 that community property systems actually worked as a conservative influence by discouraging women from earning separate wages. George McKay, A Treatise on the Law of Community Property 11 (The Bobbs-Merrill Co. 1925) (1910).

5361 Cong. Rec. 6577-84 (1921); 65 Cong. Rec. 1144-54 (1924). It was strange that community-property income splitting had so prominent a place in the Treasury Department's proposals when it involved relatively little revenue for the government, if not individual taxpayers. One questions whether it was raised for its rhetorical value. See Andrew W. Mellon, Taxation: The People's Business 61 (1924); Covey T. Oliver, Community Property and the Taxation of Family Income, 20 TEx. L. Rev. 532, 545 (1942).

54 United States v. Robbins, 269 U.S. 315 (1926).

55 Id. at 326-27.

56 Id. at 327. But see George Donworth, Federal Taxation of Community Incomes-The Recent History of Pending Questions, 4 W AsH. L. Rev. 145, 158 (1929).

57 Revenue Revision, 1925: Hearings Before the H. Comm. on Ways \& Means, 69th Cong. 146 (1925). Seligman did not mention common law devices. Id.

58 Id. 
much litigation and much confusion." 59 Professional tax advisors, on the other hand, were busy counseling taxpayers on how best to take advantage of this flexibility to minimize their clients' federal taxes. ${ }^{60}$

However, Congress did not intervene, so the executive branch was left to challenge these income-shifting devices in the courts. ${ }^{61}$ The first common law device to reach the Court involved a contract between spouses. In Lucas v. Earl, Ella Earl owned one-half of Guy Earl's wages via a contract, and the couple wanted the Court to rule that family property should be taxed to its equitable owner, Ella. ${ }^{62}$ The alternative was for the property to be taxed to the holder of legal title who, at least for a second, was Guy because he earned the wages and they were only then legally transferred to Ella. A unanimous Court again strengthened the federal government's position vis-à-vis taxpayers. ${ }^{63}$ Holmes, again writing for the Court, did not question the validity of the contract but read into the Revenue Act a broader limitation on taxpayers' ability to minimize their federal taxes. ${ }^{64}$ If the Earls' type of anticipatory arrangement was accepted as a means to divide income, he reasoned, the income tax could be avoided by those with sufficient means and foresight to plan ahead. ${ }^{65}$

The Supreme Court continued using this pragmatic approach to protect the income tax in a ruling on family trusts. A little more than a month after Earl, in Corliss v. Bowers, Holmes opined that taxation was "not so much concerned with the refinements of title as it is with actual command over the property taxed-the actual benefit for which the tax is paid." ${ }^{66}$ This unanimous opinion crafted a national approach to income taxation that made income shifting harder to achieve. Nonetheless, trusts holding investment property continued to be popular vehicles for tax avoidance, despite the fact that setting up these trusts invited litigation, "the costs of which might possibly offset any theoreti-

59 Stanley S. Surrey, Assignments of Income and Related Devices: Choice of the Taxable Person, 33 Colum. L. Rev. 791, 791 (1933).

60 See, e.g., Commerce Clearing House, Inc., 1928 United States Income and War Tax Guide 15-16 (1928); Commerce Clearing House, Inc., 1931 United States Income AND War TAx Guide 20 (1931).

61 See California Community Property-Federal Estate Tax, 35 Op. Att'y Gen. 89 (1929); Withdrawal of Opinions Relating to the Wife's Interest in the Community Income, 35 Op. Att'y Gen. 265 (1929).

62 Lucas v. Earl, 281 U.S. 111, 113-14 (1930). For a good discussion of Lucas v. Earl, see McCaffery, TAXing Women, supra note 10, at 37-45; Patricia A. Cain, The Story of Earl: How Echoes (and Metaphors) from the Past Continue to Shape the Assignment of Income Doctrine, in Tax Stories: An In-Depth Look at Ten Leading Federal Income Tax Cases 275-311 (Paul L. Caron ed., 2003). Holmes's opinion established a long-persisting difference in common law states between the tax treatment of income from services, which could not be divided between spouses, and income from investment property, which generally could be.

63 Earl, 281 U.S. at 111.

64 Id. at $114-15$.

$65 I d$.

66 Corliss v. Bowers, 281 U.S. 376, 378 (1930). The Court took a more taxpayer-friendly stance on family partnerships in 1932. Burnet v. Leininger, 285 U.S. 136 (1932). However, to manage an explosion of family partnerships in the mid-1940s, in 1946 the Court drew more-specific standards for family partnerships, making it harder to satisfy its requirements. Comm'r v. Tower, 327 U.S. 280 (1946); Lusthaus v. Comm'r, 327 U.S. 293 (1946). But see Comm'r v. Culbertson, 337 U.S. 733 (1949). 
cal tax saving." 67 These cases plagued the courts; the score was about even, with taxpayers and the government each prevailing about half of the time. ${ }^{68}$

Seven months after Corliss, another community property case was back before the Supreme Court, and this one changed the direction of tax planning. In Poe v. Seaborn, a unanimous Court held that community property married couples must divide community income equally between spouses and thereby gain the reduction in federal taxes denied the Robbinses, Earls, and Corlisses. ${ }^{69}$ Justice Owen Roberts, in his first opinion for the Court, viewed the Court as bound by state determinations of property ownership and ascribed to the Court only a limited ability to look at the actual substance of the rights state law created. ${ }^{70}$ The "vested property right" of the wife in her property became the pivotal requirement for allowing spouses to shift income for federal tax purposes, and scholars and practitioners alike were left struggling to determine what degree of ownership and control would satisfy the Court. ${ }^{71}$

As the confusion brought by Seaborn vexed the legal bar, a state law that required married couples to use a joint tax rate to calculate their state income tax liability came before the Court in Hoeper v. Tax Commission. ${ }^{72}$ Under Wisconsin law, spouses had the option to file separate returns but each spouse's tax was still computed on their combined income and the amount due by each was the proportion that his or her income bore to the total. ${ }^{73}$ The Court refused to defer to the state and disallowed using a couple's combined income to determine applicable tax rates. Hoeper also accentuated a growing division between Justices Holmes and Roberts in the year before Holmes retired. Roberts, writing for the majority, agreed with the taxpayers that Wisconsin's married women's acts removed from the marriage relationship all the elements that differentiated a married person from a single person except for purely social aspects. ${ }^{74}$ On the other hand, it remained undeniable to Holmes, in his dissent,

67 William C. Warren, The Reduction of Income Taxes Through the Use of Trusts, 34 MicH. L. Rev. 809, 813 (1936). Warren, among others, wrote blueprints on how best to use trusts. See also T.D. 5488, 1946-1 C.B. 19-25.

68 Randolph Paul, Partnerships in Tax Avoidance, 13 Geo. WAsh. L. Rev. 121, 142 n.118 (1945).

69282 U.S. 101 (1930). Erwin Griswold noted a rumor that Justices Hughes and Stone, and possibly one other Justice, wished to dissent and so simply "took no part" out of respect for Justice Robert's first opinion. Erwin N. Griswold, Owen J. Roberts as a Judge, 104 U. PA. L. Rev. 332, 338 n.5 (1955). Hughes was also known for his dislike of dissents. Paul A. Freund, Charles Evans Hughes as Chief Justice, 81 Harv. L. Rev. 4, 37 (1967).

70 Seaborn, 282 U.S. at 110.

71 See, e.g., Charles B. Collins, Community Property and Taxes $\S \S 2-3$ (1945); WiLliam Vickery, Agenda for Progressive Taxation 276-79 (1947); George T. Altman, Community Property in Peril or the Lengthening Shadow of the Clifford Case, 19 TAXES 262 (1941); Paul W. Bruton, The Taxation of Family Income, 41 Yale L.J. 1172, 1172, 1178 (1932); Oliver, supra note 53, at 532-33; Paul \& Havens, supra note 2, at 242-50; George E. Ray, Proposed Changes in Federal Taxation of Community Property: Income Tax, 30 Cal. L. Rev. 397, 404-08 (1942); Sebree, supra note 52, at 301-02; Paul R. Trigg, Jr., Some Income Tax Aspects of Community Property Law, 46 Mich. L. Rev. 1 (1947).

72 Hoeper v. Tax Comm'n, 284 U.S. 206, 216 (1931).

73 Wis. STAT. $\$ 71.09(4)(\mathrm{c})$ (1929), invalidated by Hoeper, 284 U.S. at 213-18. This differs from married filing separately, in which each spouse reports his or her own income and does not need the couple's total income to determine applicable rates.

74 Hoeper, 284 U.S. at 215. 
that however emancipated a wife may have become, it was reasonable for a state to assume her income still directly affected her husband's ability to pay taxes. $^{75}$

By neither the Court nor Congress creating a national system for determining property ownership for federal income tax purposes, the American system empowered states to game the federal income tax to benefit narrow interests. The interests served were narrow because few Americans paid any federal income tax in this era and so few stood to gain from income shifting. ${ }^{76}$ As the income tax became a tax that applied to a majority of American workers between 1939 and 1947, five states and one territory adopted community property regimes, a law they otherwise would not have considered adopting, in order to enjoy this growing tax savings permitted by the Court. ${ }^{77}$ Many more states seriously considered doing the same, and only Congress's intervention in 1948 prevented a domino effect. ${ }^{78}$

Tax avoidance by couples using both community property and common law devices increased in frequency and became more costly to the government as tax rates rose during the Great Depression and World War II. ${ }^{79}$ Four months after Franklin D. Roosevelt's inauguration, reformer and future Supreme Court Justice Felix Frankfurter advised him to crack down on tax cheats. ${ }^{80}$ Frankfurter's concern was pragmatic: he insisted that the federal government was losing millions of tax dollars every year, principally through poor enforcement, which included the allowance of income-shifting devices. ${ }^{81}$ In a 1935 press conference, Roosevelt reported that one family had established 197 trusts to divide family income and have it taxed at lower rates; that thirty-two millionaires had not paid tax on 37 percent of their incomes; that gifts were used to reduce one $\$ 100$ million estate to $\$ 8$ million two years prior to one man's death. $^{82}$

Tax avoidance by the wealthy received such attention because much of the public blamed them for the Great Depression. ${ }^{83}$ Even before Roosevelt's inauguration, President Herbert Hoover had established a Senate Banking Commission to investigate abuse in the finance industry. ${ }^{84}$ Some of the most outrageous behavior this commission uncovered, and therefore could show the

75 Id. at 219-20.

76 See Brownlee, Federal Taxation, supra note 33, at 63.

77 See McMahon, To Save State Residents, supra note 51, at 620; Jones, supra note 10, at 273; Sturiale, supra note 51, at 215. For a good comparison of the laws, see William Q. de Funiak, The New Community Property Jurisdictions, 22 Tul. L. Rev. 264, 264 (1947).

78 McMahon, To Save State Residents, supra note 51, at 620-22.

79 See id.; Jones, supra note 10, at 273-74.

80 Joseph Jacobs Thorndike, III, The Price of Civilization: Taxation in Depression and War, 1933-1945, at 304 (May 2005) (unpublished Ph.D. dissertation, University of Virginia). Frankfurter, in turn, was pushed by progressive Justice Louis Brandeis. Letters from Louis Brandeis to Felix Frankfurter (Mar. 24, 1932 \& Jan. 21, 1933) in Half-Brother, HalfSon: The Letters of Louis D. Brandeis to Felix Frankfurter 481-82, 508-09 (Melvin I. Urofsky \& David W. Levy eds., 1991).

${ }^{81} I d$.

82 Press Conference \#225, Executive Offices of the White House, July 31, 1935, in 6 THE Press Conferences of the President 67-70 (1957).

83 Ferdinand Pecora, Wall Street Under Oath 204-05 (1939).

${ }^{84} I d$. 
American public, was wealthy bankers selling stock to their spouses to trigger tax losses to offset other income. ${ }^{85}$ One junior partner of J.P. Morgan, Thomas S. Lamont, sold depreciated securities to his wife in the last days of December 1930, her purchase price funded with a promissory note. Three months later, he bought the securities back at the same price, allowing his wife to pay off her note in full. ${ }^{86}$ Even worse was Charles E. Mitchell, president of the National City Bank, now Citibank, whose intra-familial sales landed him first in criminal, and then civil, court. ${ }^{87}$ Although Lamont's sales lacked economic substance, for the most part they did have the form of actual sales. Mitchell, on the other hand, did not deign to give his transactions even the appearance of genuine sales and simply wrote a letter to his wife conveying National City securities to her ${ }^{88}$ The Commission and the public refused to accept that this sale to his wife was bona fide, despite the fact that Mitchell maintained it was so under oath. ${ }^{89}$ Even Mitchell had to admit, however, that he had originally sold this stock "frankly for tax purposes." 90

In 1933, as Acting Secretary of the Treasury Department, Morgenthau asked Congress to tax husband and wife as a single unit as part of a tax-reform effort to eliminate these tax shams. ${ }^{91}$ Morgenthau's proposal would have eliminated both community property and common law means of tax avoidance by

85 One estimate was that $\$ 7$ billion of securities were transferred between spouses. Revenue Revision of 1942: Hearings on H.R. 7378 Before the H. Comm. on Ways \& Means, 77th Cong. 3310 (1942) [hereinafter Hearings on H.R. 7378 Before the H. Comm. on Ways \& Means]. Secretary of the Treasury Andrew Mellon also sold stocks to relatives to trigger losses. Robert H. Jackson, That Man: An Insider's Portrait of Franklin D. Roosevelt 125 (John Q. Barrett ed., 2003).

86 This series of activities triggered what became a disallowed tax loss of $\$ 114,807$. T.S. Lamont Lists Stock Sold Wife, N.Y. Times, June 10, 1933, at 7; Mellon Hits Back; Asks a Tax Refund, N.Y. Times, May 26, 1934, at 5; Lamont Tax Case Settled, Wall St. J., May 26, 1934, at 14; Pecora, supra note 83, at 196; Arthur M. Schlesinger, Jr., 3 The Politics of Upheaval: The Age of Roosevelt, 1935-1936, at 253 (1988).

87 PecorA, supra note 83, at 195-96; Damnation of Mitchell, Time, Mar. 6, 1933, at 47; Mitchell Settles Income Tax Claims, N.Y. Times, Dec. 29, 1938, at 1; Mitchell's Gifts to Wife Attacked, N.Y. Times, May 20, 1933, at 1.

88 The 1929 sale triggered a $\$ 2.8$ million loss that Mitchell deducted, eliminating any federal tax obligation for 1929. Mitchell's Gifts to Wife Attacked, supra note 87, at 1; Damnation of Mitchell, supra note 87, at 47. Mitchell was acquitted of the criminal charges, but, after the civil trial, was required to pay $\$ 700,000$ in back taxes and, on December 29, 1938, more than $\$ 1.25$ million with interest and penalties was discharged. PECORA, supra note 83, at $195-96$.

89 PeCORA, supra note 83, at 194.

$90 \mathrm{Id}$.

91 Income splitting uses favorable rate brackets as an incentive for couples to use the couple as their unit instead of requiring them to do so. Memorandum from Tarleau to Sullivan, Legislative History of Compulsory Joint Returns (June 10, 1941) (available at http://taxhistory.tax.org/Civilization/Documents/marriage/hst28693/28693-1.htm); U.S. DEP' т of THE Treasury, 73d Cong., Statement of Acting Secretary of the Treasury Regarding the Preliminary Report of a Subcommittee of the Committee on Ways and Means 15, 20 (Comm. Print 1933) [hereinafter Statement of Acting Secretary]. To satisfy constitutional concerns, the proposal apportioned tax obligations between spouses according to their relative shares of the income. Community Property Income: Hearings on H.R. 8396 Before a Subcomm. of the H. Comm. on Ways \& Means, 73d Cong. 23-24 (1934) [hereinafter Hearings on H.R. 8396]. 
requiring a mandatory joint return that used the same rate brackets applicable to single taxpayers. ${ }^{92}$ In Morgenthau's view, individual filing threatened to "defeat the progressive rate schedule, particularly in the case of the larger taxpayers." 93 This was true whether a couple's income was earned by the husband, wife, or a combination of the two.

In December 1933, Treasury Department officials were disappointed when the House Subcommittee on Tax Avoidance summarily rejected their mandatory joint return plan. ${ }^{94}$ In its place, the House substituted a management and control test, so that whichever spouse controlled the income would have to report it. ${ }^{95}$ This proposal was rejected quickly in the House, largely due to opposition from community-property state representatives. ${ }^{96}$ The next year, worried that "such [a] controversial item might delay the passage of the revenue bill," the House Ways and Means Committee refused the Treasury Department's plea to address income-shifting devices. ${ }^{97}$ A similar attempt by the Treasury Department to target these devices failed in $1937 . .^{98}$

When these plans failed, the Treasury Department abandoned the unitary approach it had generally applied to married couples since 1913. No longer would it try to preserve equity between couples, as opposed to within couples, by preventing couples from gaining an advantage through tax planning. The Department issued new regulations in 1935 requiring that a husband and wife, regardless of whether they filed jointly or separately, be considered separate taxpayers. ${ }^{99}$ This maximized the possible returns from income shifting because couples, if they shifted income, could double dip into low tax brackets regardless of how they chose to file their returns.

92 Statement of Acting SeC'y, supra note 91, at 15.

93 Revenue Revision, 1934: Hearings Before the H. Comm. on Ways \& Means, 73d Cong. 113 (1934).

94 See Tarleau, supra note 91; Hearings on H.R. 8396, supra note 91, at 6.

95 The first chief of staff of the Joint Committee on Internal Revenue Taxation proposed a management and control test in 1933 that would tax income to the spouse who controlled it. Hearings on H.R. 8396, supra note 91, at 18.

96 See Tarleau, supra note 91.

97 The Ways and Means Committee did consider the community property question in ten forlorn days of hearings over H.R. 8396. Hearings on H.R. 8396, supra note 91, at 6; Community Property Tax Revision Urged, L.A. Times, May 2, 1934, at 1; Property Tax Plan Assailed, L.A. Times, May 22, 1934, at 11. There was no mention of the hearings in the New York Times, Washington Post, or Wall Street Journal. Common law devices also attracted little public attention at this time.

98 See S.J. Res. 155, 75th Cong. (1937); H.R. Doc. No. 75-260, at 4 (1937); Tax Evasion and Avoidance: Hearings Pursuant to Pub. Res. 40 Before the J. Comm. on Tax Evasion and Avoidance, 75th Cong. 309 (1937); H.R. Doc. No. 75-337, at 7 (1937). For a good discussion, see Randolph E. Paul, The Background of the Revenue Act of 1937, 5 U. CHI. L. Rev. 41, 84-85 (1938). The Treasury Department reviewed the question of the tax unit as part of comprehensive examinations of the federal income tax system in 1934 and 1937. CARL Shoup, U.S. Dep't of the Treasury, The Federal Revenue System: A Report to the Secretary of the Treasury (1934), http://www.taxhistory.biz/Civilization/Documents/ Surveys/hst23735/23735-1.htm; Louis Shere, Tax Revision 1937-Project No. 3, Miscellaneous and Administrative Tax Changes 1-2 (1937) (on file with author).

99 See Treas. Reg. § 86, art. 51-1, 117-5, at 129, 218 (1935); G.C.M. 15438, 14-2 C.B. 157 (1935). 
On the other hand, a policy of jointness reflected the expectations of most American families. ${ }^{100}$ Married couples had filed joint tax returns in the 1930s, even when there was little economic incentive to do so other than administrative convenience. In 1938, for instance, 6.15 million income tax returns were filed of which 3.2 million, or almost 52 percent, were filed by married persons. ${ }^{101}$ Of that 3.2 million, only 350,000 (or 5.7 percent of all returns and 10.9 percent of returns from married persons) were the separate returns of husbands or wives. Married couples filing separately, however, claimed 22 percent of the aggregate income for all couples filing returns, showing that wealthy couples had learned the benefits of filing separately and, most likely, shifting income to be taxed in lower tax brackets. ${ }^{102}$

The relatively small number of tax returns being filed helps explain why this issue was not legislatively resolved before World War II. "In most years before 1940, taxable returns covered less than 5 percent of the population ... and less than 30 percent of the total of individual incomes."103 By 1945, about 74 percent of the population filed taxable returns that covered 83 percent of incomes. ${ }^{104}$ This change made the determination of the tax unit more important. However, it remained uncertain whether mandatory joint filing would be permissible after Hoeper. ${ }^{105}$ Roosevelt's Treasury Department risked a challenge on these grounds in 1941 and in 1942. Secretary Morgenthau took the position that the family as a whole was the unit that should be used as the basis for testing how much its members could pay in taxes. ${ }^{106}$

Although Morgenthau was convinced that a family's total wealth properly reflected its ability to pay taxes, it was wartime revenue demands that really drove revenue-increasing mandatory joint return proposals that required that husbands and wives combine their incomes on a single joint return and be taxed at rates equal to those applied to single taxpayers. As "Rosie the Riveter" entered the paid labor market, potential revenue was lost by individual filing, but the real tax revenue to be gained was from ending the benefit of income shifting. ${ }^{107}$ The Roosevelt administration adopted this approach after it determined that it would yield an additional $\$ 300$ million in taxes. ${ }^{108}$ Administra-

100 This Article does not seek to explain why couples chose to act this way. However, this unitary view of the family worked well with the Depression-era desire to redistribute jobs. With high national unemployment, there was widespread public opposition to married women working. See Susan Ware, Beyond Suffrage: Women in the New Deal 2 (1981); KesSler-HARRIS, supra note 10, at 56-57.

101 S. REP. No. 77-673, at 11 (1941).

102 Id.

103 Lawrence H. Seltzer, The Personal Exemptions in the Income Tax 58 (1968).

104 Id.; Dennis J. Ventry, Jr., Equity Versus Efficiency and the U.S. Tax System in Historical Perspective, in The Ongoing Debate: Tax Justice 25, 34 (Joseph J. Thorndike \& Dennis J. Ventry, Jr. eds., 2002).

105 See supra text accompanying note 74.

106 Revenue Act of 1942, Hearings on H.R. 7378 Before the S. Comm. on Finance, 77th Cong. 6 (1942) [hereinafter Hearings on H.R. 7378 Before the S. Comm. on Finance]; see also Hearings on H.R. 7378 Before the H. Comm. on Ways \& Means, supra note 85, at 9. 107 The Treasury Department also suggested a two-earner credit, infra pp. 735-736, which would have sheltered most of Rosie's earned income.

108 H.R. ReP. No. 77-1203, at 10 (1941) (Conf. Rep.). Separate returns cost \$343 million annually, more than 40 percent of federal income tax collections. Memorandum from Coyle 
tive convenience also made the proposal attractive: it was hard for administrators to determine which of the common law devices were legitimate, therefore increasing the amount of resources devoted to examining the growing number of returns. ${ }^{109}$

Thus, the Treasury Department tried to target all income shifting, but the mandatory joint return proposal was most popular when portrayed as eliminating the discrimination between states resulting from the community property advantage. ${ }^{110}$ The largest increase in the number of joint returns would come from community property states, but only $\$ 65$ million of the additional revenue that would have been raised would come from eliminating community property's favorable treatment; $\$ 288$ million would be derived from eliminating common law income shifting. ${ }^{111}$

Motivated by the administration's position and the need for revenue, the Ways and Means Committee included in the 1941 revenue bill a mandatory joint return provision. ${ }^{112}$ The argument that the majority of the committee found most effective rhetorically was that, under existing law, if a husband earned all the couple's income, the couple would be disadvantaged compared to a couple in which both spouses earned wages and, thus, could file separate returns. ${ }^{113}$ For supporters of the mandatory joint return, the most effective argument was not attacking income-shifting tax avoidance but, rather, implicitly criticizing families whose wives worked. However, the bill's authors attempted to balance any detriment that the proposal might cause working

to Div. of Tax Research, U.S. Dep't of the Treasury, Joint Returns of Income of Husbands and Wives (Apr. 15, 1941) [hereinafter Memo on Joint Returns of Income] (available at http://www.taxhistory.org/Civilization/Documents/marriage/hst28695/28695-1.htm). Morgenthau estimated that eliminating separate returns could raise $\$ 400$ million. Hearings on H.R. 7378 Before the S. Comm. on Finance, supra note 106, at 8-9, 27.

109 Administration was estimated to cost $\$ 1.56$ per return for which tax was paid and $\$ 0.50$ if tax was not paid. Roy Blough, Problems of Federal Tax Administration, 214 Annals Am. Acad. Pol. \& Soc. ScI. 157, 158 (1941).

11094 Cong. Rec. 789, 805, 894 (1948); 88 Cong. Rec. 6260, 6269, 6636 (1942); Cong. Rec. 6,617 (1941). The Senate Finance Committee had come to recognize that if it extended income splitting to couples in all states:

[t]he incentive for married couples in common-law States to attempt the reduction of their taxes by the division of their income through such devices as trusts, joint tenancies, and family partnerships will be reduced materially. Administrative difficulties stemming from the use of such devices will be diminished, and there will be less need for meticulous legislation . . . .

S. ReP. No. 80-1013, at 25 (1948). The Senate blamed the creation of common law devices on the community property advantage. Id. at 23-24.

111 Staff of Joint Comm. on Internal Revenue Taxation, 77th Cong., Mandatory Joint Returns Prepared for the Use of the Committee on Ways and Means 11 (Comm. Print, 1941); Memo on Joint Returns of Income, supra note 108. Community property states gained significantly in population and political power during World War II, making it increasingly unlikely this tax advantage would be revoked.

112 H.R. Rep. No. 77-1040, at 10-22 (1941). While focusing most of its attention on the community property advantage, the Ways and Means Committee did make note of common law devices. Id. at 13 .

113 See id., at 11-12 (1941). For a discussion of the division on this issue along class lines within the women's movement, see Stephanie Hunter McMahon, Money, Sex, and Tax Politics: Developments in Tax Avoidance and Marital Tax Returns, 1913-1948, at 239-41, 241-45 (Jan. 2009) (unpublished Ph.D. dissertation, University of Virginia) (on file with author). 
wives, at least the part that could be measured in economic terms, with an earned income credit for couples with two earners. ${ }^{114}$ This would have sheltered from taxation most of the income produced by working wives and would have been the first tax-savings provision specifically targeted to two-earner couples.

Although the Treasury Department still wanted a mandatory joint return, by the time the bill reached the Senate, Morgenthau was willing to sacrifice the provision to get a revenue bill passed quickly. He complained that seven months of the year had already elapsed, which had cost the government substantial revenue. ${ }^{115}$ Community property representatives, for their part, were willing to delay passage of the revenue bill in order to defeat the mandatory joint return. Threatening filibuster, Senator Tom Connally, of Texas, warned: "Long and arduous debate will plainly be involved .... It is not unlikely that the Treasury will lose four or five times as much as from the resulting delay in enacting the excise taxes as they will gain from this provision even if finally adopted." 116 The provision was eliminated during debate in the full Senate but with the understanding that it would be the subject of a later bill. ${ }^{117}$ In 1942, Morgenthau's proposal did not make it out of the House. ${ }^{118}$

With this failure of the mandatory joint return proposals, no further action was taken until after the war, when a federal budget surplus opened up new possibilities. In response to renewed lobbying by residents and representatives of common law states and flush with a $\$ 6.8$ billion surplus in government revenue, Congress enacted a bill effectively allowing all couples to split income between spouses regardless of its ownership attributes under state law. ${ }^{119}$ The Revenue Act of 1948 used a significant portion of the post-war surplus, between $\$ 800$ million and $\$ 1$ billion, to accomplish that goal, even though the savings only benefited 10 percent of all married taxpayers. ${ }^{120}$

The tax cuts finalized in 1948 were first proposed in a way that would not address this issue of inter-spousal income shifting. Early in 1947, Republican Ways and Means Committee Chairman Harold Knutson proposed across-the-

114 See Revenue Act of 1941: Hearings on H.R. 5417 Before the S. Comm. on Finance, 77th Cong. 7-8 (1941) [hereinafter Hearings on H.R. 5417]; Memorandum from Atlas to Blough, Earned Income Credit Under Joint Returns (June 9, 1941) (on file with author). Mandatory joint returns would raise $\$ 287$ million in taxes, but the credit would cost \$29 million. Hearings on H.R. 5417, supra, at 8-9. Congress ruled out imposing joint and several liability to avoid constitutional attack, despite the fact it had imposed joint and several liability on joint returns three years earlier. H.R. Rep. No. 77-1040, at 17-22 (1941); H.R. ReP. No. 75-1860, at 29-30 (1938). When reintroduced in 1942, the plan included similar provisions. See Hearings on H.R. 7378 Before the H. Comm. on Ways \& Means, supra note 85, at 9-10.

115 Hearings on H.R. 5417, supra note 114, at 1.

116 Id. at 1571; see also 93 Cong. Rec. 5921 (1947); The Congress, Time, Sept. 15, 1941, at 13 . The Finance Committee's report did risk Connally's ire by targeting community property income splitting. S. REP. No. 77-673, at 36 (1941).

117 H.R. ReP. No. 77-1203, at 10 (1941).

11888 Cong. Rec. 6,319-20 (1942).

119 H.R. ReP. No. 80-180, at 7 (1947); Revenue Act of 1948, Pub. L. No. 80-471, § 103, 62 Stat. 110, 111 (1948).

120 MCCAFFERY, supra note 10, at 54. 
board tax rate cuts. ${ }^{121}$ President Harry S. Truman thought that the revenue surplus would be short-lived and could be put to better use, so he vetoed the bill. ${ }^{122}$ Later in 1947, they repeated this exchange. ${ }^{123}$ Then, as Congress and the president struggled over tax reduction, the issue of the appropriate tax unit (either individuals or married couples) again became part of the debate. ${ }^{124}$ Congressional Republicans sought to garner enough votes to override a Truman veto by including in their first revenue bill of 1948 specialized provisions that targeted various interest groups, including a provision intended to eliminate the relative tax advantage that community property states were said to enjoy. ${ }^{125}$ Thus, to accomplish a tax-cutting objective, the Revenue Act of 1948 eliminated one opportunity for tax gamesmanship between states and effectively eliminated the gains from inter-spousal income-shifting devices by extending income splitting to all couples. ${ }^{126}$

Wealthy married couples therefore gained a significant first-mover advantage in that once means to achieve tax savings had been won through effective tax planning, their elected representatives sought to preserve the economic results. ${ }^{127}$ Although the 1948 Revenue Act resolved the immediate need for providing a tax cut to wealthy taxpayers and making income splitting secure without the need for individualized tax planning, it did so without resolving the underlying ambiguity of who owned what within a marriage. This problem was effectively covered over, at least for the short term, in 1948. Ownership remained the basis of taxation; however, after 1948 the question of ownership

121 Individual Income Tax Reduction: Hearings on H.R. 1 Before the H. Comm. on Ways \& Means, 80th Cong. 1 (1947).

122 H.R. Doc. No. 80-322, at 3 (1947).

123 The Hearings on H.R. 1 only delayed its effective date. See H.R. Rep. No. 80-795, at 17 (1947); S. Rep. No. 80-468, at 2 (1947); H.R. Doc. No. 80-407, at 3 (1947).

124 In a Gallup poll in mid-1947, 74 percent agreed that spouses should be able to "divide their income equally between themselves to reduce their income tax." George H. Gallup, The Gallup Poll: Public Opinion 1935-1971, at 633 (1972). Although men favored nationalized income splitting more than women, the minimal difference between the sexes does not suggest women felt there was an underlying feminist issue. Id. Support increased with the wealth of those polled. Id. In 1948, the number polling yes increased to 77 percent. $I d$. at 686 . These polls likely reflected more of a desire for tax reduction than well-thoughtout views on policy.

125 Community property couples benefited by the repeals of gift and estate tax amendments enacted in 1942, and because they would be able to split separate income between spouses. Revenue Act of 1942, Pub. L. No. 77-753, §§ 402, 453, 56 Stat. 798, 941, 953 (1942), repealed by Revenue Act of 1948, Pub. L. No. 80-471, §§ 351, 371, 62 Stat. 110, 116-17, 125 (1948); see also Willard S. Pederson, Application of Federal Income, Estate and Gift Tax Laws to Community Property, 45 Мich. L. Rev. 409, 412-13 (1947).

126 This Article does not challenge the conclusion that the tax system reflects America's views on gender or that those views limit policymakers' choices. Within that framework, however, the government had many means to accomplish its goals.

127 Few considered who would be disadvantaged. Little discussion of single taxpayers, poor couples, and those wealthy couples with two relatively equal earners (though rare for the period) was raised in Congress. See, e.g., H.R. ReP. No. 80-1274, at 74-75 (1948); Reduction of Individual Income Taxes: Hearings on H.R. 4790 Before the S. Comm. on Finance, 80th Cong. 262, 277, 291 (1948). The Revenue Act of 1948 did raise the maximum standard deduction for single persons to that of joint filers. Revenue Act of 1948, Pub. L. No. 80-471, $\S 302$, 62 Stat. 110, 114-15 (1948). 
only had to be narrowed to the marital unit. This relieved the federal government of solving the riddle of ownership within most families.

\section{Compliance in the Modern Era}

As shown in the previous section, before Congress nationalized income splitting via the joint return in 1948, the federal government had difficulty policing married couples' efforts to reduce their collective taxes. Although aware that income shifting was a problem in both community property and common law states, the government found it almost impossible to prevent this behavior or to ensure that income shifting was only recognized for tax purposes when there were substantive changes in property ownership. The IRS was left grappling with rules that never seemed to anticipate the next income-shifting device. We should not expect today's IRS to be significantly better equipped to manage this type of tax avoidance, and its failure to do so will have significant negative consequences for our federal revenue system.

If anything, the IRS's job has become more, rather than less, difficult since 1948. On a budget of about $\$ 10.6$ billion, IRS now collects almost $\$ 2.25$ trillion a year compared to collecting $\$ 15.4$ billion in 1948 on a budget of $\$ 188$ million. ${ }^{128}$ This means that in 19481.22 percent of the revenue collected was spent raising it; in 2007, only 0.47 percent of the revenue raised was spent raising it. Although the IRS continues to "strive[ ] to maintain the fairest and most effective system of voluntary tax compliance in the world," it is hard to collect so much money. ${ }^{129}$ The job is made more difficult because of the growing complexity of the Internal Revenue Code. ${ }^{130}$ In 2010, the Code contained more than 690 separate provisions and was accompanied by more than 20,000 pages of regulations. ${ }^{131}$ This complexity, in turn, imposes substantial obligations on taxpayers to comply with the rules and on the IRS to interpret the law and to make sure that taxpayers are meeting their obligations. For example, the 2009 Form 1040 had seventy-six lines, including eleven schedules and thirtytwo worksheets, which required 161 pages of instructions; the 1948 version had ten lines with seven schedules and two worksheets.

Not only has the tax system that revenue agents must learn, understand, and apply become more complex, but there has also been a dramatic increase in the number of returns that have to be monitored. Since 1948, the total number

128 Tax Fairness: Policy and Enforcement: Hearing Before the H. Subcomm. on Fin. Servs. \& Gen. Gov't Comm. on Appropriations, 110th Cong. 2 (2007) [hereinafter Olson, Tax Fairness], available at http://www.irs.gov/pub/irs-utl/nta_testimony_houseapprops_030507_v7. pdf (written statement of Nina E. Olson, National Taxpayer Advocate). The IRS actually collected $\$ 2.51$ trillion on a gross basis in 2006 but issued $\$ 277$ billion in tax refunds. Id. at 2, n.4; Historical Statistics of the United States, Millennial Edition On line 5-112 tbl.Ea740-747, http://hsus.cambridge.org/HSUSWeb/table/showtablepdf.do?id=Ea740-747; H.R. Doc. No. 81-3, at 135 (1948).

129 U.S Dep't of the Treasury, IRS Strategic Plan, 2009-2013, at 3, http:// www.irs.gov/pub/irs-pdf/p3744.pdf (last visited Jan. 29, 2011) [hereinafter IRS STRATEGIC Plan].

130 Scholar Steve Johnson suggests a moratorium on new legislation in order to allow the IRS to catch up with the rules. See Johnson, supra note 16, at 1050-51.

131 See generally I.R.C. and Treasury Regulations. 
of tax returns filed grew by almost 188 percent, from a little more than 52 million to more than 150 million in $2008 .{ }^{132}$ The number of returns will continue to increase, and returns that are more complicated to audit are expected to grow at a faster rate. Between 2009 and 2017, the IRS expects the number of individual returns to grow by more than 5 percent and those from small businesses and self-employed taxpayers, the group who can most easily avoid taxes and have the most complicated returns, to grow by almost 12 percent. ${ }^{133}$

As the IRS juggles an increasingly complex Code and ever more taxpayers, it also faces more tasks, some beyond its historical expertise. The IRS has over a decade of experience operating under the Restructuring and Reform Act of 1998 and still struggles under its broadening mandate. ${ }^{134}$ Worried that the IRS was overzealous in its pursuit of tax revenue, Congress required that the IRS give renewed attention to taxpayers as "customers," which meant expanding many programs, such as innocent spouse relief, that are resourceintensive. ${ }^{135}$ With this change in focus, the IRS "shifted substantial resources from enforcement to taxpayer service." 136 Moreover, while the IRS collects more than 96 percent of the federal government's revenue, it is also tasked with dispensing stimulus checks and other forms of aid, such as the Earned Income Tax Credit (EITC). ${ }^{137}$ Former Commissioner Margaret M. Richardson complained that tax credits might win votes for politicians, but they make administering the tax system nearly impossible. ${ }^{138}$

The IRS must do this diverse work with younger and less experienced employees as it hires new employees to replace those eligible for retirement. ${ }^{139}$ In 2002, IRS staffing for examinations of tax returns was down almost 20 per-

132 Id. Historical Statistics, supra note 128, at 5-112 tbl.Ea740-747. Christian, in her work on joint and several liability, argues that individual filing will be administrable, but many of the government's attempts she relies on were before the income tax was a mass tax. Christian, supra note 12 , at 560-63.

133 Treasury Inspector Gen. for Tax Admin., Filing Characteristics and Examination Results for Small Business Corporate Returns 3 (2010); I.R.S. Doc. 6292, Fiscal Year Return Projections for the United States 2010-2017, at 8 (2010), available at http:// www.irs.gov/pub/irs-soi/d6292.pdf.

134 IRS Restructuring and Reform Act of 1998, Pub. L. No. 105-206, 112 Stat. 685 (1998); Lederman, supra note 16, at 980-83; Johnson, supra note 16, at 2. Subsequent to the 1998 Act's enactment, many of the horror stories used to develop support for the bill were discovered to be unfounded or exaggerated. Office of Special Investigations, U.S. Gen. Accounting Office, GAO Report on Allegations of IRS Taxpayer Abuse, TAx Notes TodAy, Apr. 25, 2000; Joe Spellman, Caplin, Panel Ponder Consequences of Finance Hearing Horror Stories, Tax Notes Today, June 23, 1999; Ryan J. Donmoyer, GOP Opens IRS Horror Story Web Site, 77 Tax Notes 667, 667 (1997); David Cay Johnston, Inquiries Find Little Abuse by Tax Agents: '98 Law Keeps I.R.S. Extremely Cautious, N.Y. Times, Aug. 15, 2000, at C1.

135 Johnston, Inquiries Find Little Abuse by Tax Agents, supra note 134.

136 Lederman, supra note 16, at 982. This reduced examination programs by 605 staff years. Id.

137 IRS Oversight Bd., Annual Report to Congress 2008, at 3 (2009) [hereinafter IRS Oversight Bd., Annual Report 2008], available at http://www.treas.gov/irsob/reports/ 2009/2008_annual_report.pdf.

138 Sheryl Stratton, Former Commissioners See Challenges Facing the Tax System, TAx Notes Today, Feb. 14, 2002.

139 Treasury Inspector Gen. for Tax Admin., Trends in Compliance Activities Through Fiscal Year 2009, at 2 (2010) [hereinafter Trends in Compliance 2009]. 
cent from 1996. ${ }^{140}$ After hitting a low point in hiring in 2005, a recent roller coaster of hiring initiatives has improved compliance efforts but, nevertheless, the IRS will not enjoy an immediate benefit from its recent hires because of its training demands. ${ }^{141}$ More than half of the department's employees are older than fifty years old, and many are eligible for retirement. ${ }^{142}$ More hiring will be necessary to fill the ranks. Moreover, some areas of enforcement have increased their efforts but others have retained lower 2008 levels. ${ }^{143}$ Although these statistics are discouraging, the IRS has proved that it can do much with little. In recent years, the IRS has increased its efficiency as its workforce shrunk. ${ }^{144}$ The overall percentage of tax returns examined increased in 2007 by almost 9 percent even though the number of examination personnel decreased by just over 4 percent. ${ }^{145}$ But with the increase in employee workloads averaging 1.5 to 2 percent per year, the question is how long the IRS can continue to do so. ${ }^{146}$

With all of these demands, it should not be surprising that there is not enough money to do everything that needs to be done. Former Commissioner Charles O. Rossotti complained that the IRS was "winning the battle but losing the war" and detailed the consequences of the IRS's lack of adequate funding. ${ }^{147}$ The IRS, he claimed, has to forego pursuing cases worth $\$ 29.9$ billion each year due to lack of resources and, even worse, is losing an estimated six to twelve times this amount in the indirect benefits of broader compliance that more vigorous enforcement would encourage. ${ }^{148}$ Currently, the IRS gets a budget of forty-one cents per return, ten cents less than in 1997 after adjusting for inflation. ${ }^{149}$ The National Taxpayer Advocate is concerned that, because the IRS does not receive sufficient funding, it cannot treat taxpayers fairly. ${ }^{150}$

140 Internal Revenue Serv., U.S. Dep't of the Treasury, Report to Congress: IRS Tax Compliance Activities 2 (2003), available at http://www.irs.gov/pub/irs-soi/ 03congressrpt.pdf.

141 Trends in Compliance 2009, supra note 139, at 8.

142 IRS Strategic Plan, supra note 129, at 9.

143 Trends in Compliance 2009, supra note 139, at 8.

144 IRS Oversight Bd., FY2009 IRS Budget Recommendation: Special Report 8 (2008) [hereinafter IRS Oversight BD., FY2009 Special Report], available at http:// www.treasury.gov/irsob/reports/2008/FY09-BudgetReport.pdf.

145 Treasury Inspector Gen. for Tax Admin., Trends in Compliance Activities Through Fiscal Year 2007, at 3 (2008) [hereinafter Trends in Compliance 2007]. In 2007, slightly more than 71 percent of all examinations were by correspondence. Id. at 7 . As a result of cost and government philosophy, the examination rate hit a low in 2000 when only 0.49 percent of all individual returns were examined, but by 2008 the rate had risen to 1.01 percent. IRS Oversight Bd., Annual Report 2008, supra note 137, at 14.

146 IRS Oversight BD., FY2009 Special Report, supra note 144, at 8.

147 Olson, Tax Fairness, supra note 128, at 4. Rossotti sought a 51 percent increase in the IRS's enforcement budget. David Cay Johnston, Departing Chief Says the I.R.S. Is Losing Its War on Tax Cheats, N.Y. Times, Nov. 5, 2002, at A1. "Due to a lack of proper funding, the agency has found itself in an impossible situation when it comes to enforcing the tax laws." W. Edward Afield, Agency Activism as a New Way of Life: Administrative Modification of the Internal Revenue Code Through Limited Issue Focused Examinations, 7 FLA. TAx Rev. 455, 457 (2006).

148 Olson, Tax Fairness, supra note 128, at 4-5.

149 Johnston, supra note 147.

150 Olson, Tax Fairness, supra note 128, at 1. 
To meet all of its current needs, the IRS needs more money, and this economic reality is not likely to change. One reason for the resource gap is that Congress treats funding the IRS as it does other forms of discretionary spending. ${ }^{151}$ Under current budget procedures, a spending ceiling is established for a broad category of programs, including the Departments of the Treasury, Transportation, Housing and Urban Development, the Judiciary, the District of Columbia, and independent federal agencies. Then, this designated amount is allocated among the departments, making them competitors for the limited pool of funding. ${ }^{152}$ Virtually all of those departments are more popular among voters than the IRS. Indeed, according to the IRS Oversight Board:

[T] he reason that the IRS does not get adequately funded is that there is no powerful constituency that champions the IRS. No member of Congress ever got a single vote by telling his constituency that he got more resources for the IRS. . . . There are never enough resources to do everything that is wanted and needed and the IRS loses in the priority battle. ${ }^{153}$

One scholar has noted that despite the need to increase the IRS's budget, the reality is that it "indeed borders on the politically impossible." 154

The lack of funding for enforcement activities is problematic because tax avoidance often exploits vague statutory language and illusive congressional intent, sometimes crossing into downright illegal evasion. The result is that the behavior is hard to police. In 2001, the latest year for which statistics are available, the gross "tax gap" - the gap between the amount taxpayers owe in taxes and what they pay-was $\$ 345$ billion and the net tax gap, which includes revenue collected after late payments and enforced collection, was $\$ 290$ billion. ${ }^{155}$ And while, since 2000, the IRS has reversed many of the downward trends in compliance, the total dollar amount of uncollected liabilities increased to a tenyear high, and the gap between new delinquent account receipts and closures of accounts had widened by almost 63 percent by the end of $2007 .{ }^{156}$

The economic pressure placed on the IRS makes it hard to enforce areas ripe for exploitation by income shifting because other areas of enforcement also demand high priority. For example, noncompliance by business and high net worth individuals is currently given less attention than complex international transactions used to avoid taxes. ${ }^{157}$ Over 48.9 percent of the cost of all

151 IRS Oversight BD., FY2009 SPECIAL Report, supra note 144, at 27.

152 The IRS and the Tax Gap: Hearing Before the H. Comm. on the Budget, 110th Cong. 7 (2007) [hereinafter Olson, Tax Gap], available at http://www.irs.gov/pub/irs-utl/ nta_housebudget_testimony_021607.pdf (written statement of Nina E. Olson, National Taxpayer Advocate).

153 George Guttman, The IRS's Fiscal 2004 Budget: More or Less?, 98 TAx Notes 486, 487-88 (2003) (quoting Larry Levitan). Former Commissioner Fred Goldberg, Jr. complained, "[T]he IRS is an inviting political target." Sheryl Stratton, Former Commissioners See Challenges Facing the Tax System, 94 TAx Notes 693, 694 (2002).

154 Johnson, supra note 16, at 1014. Much of any increase in budget covers mandatory cost increases, such as government-wide pay increases and the associated costs of fringe benefits. See Guttman, supra note 153, at 486.

155 Office of Tax Policy, U.S. Dep't of the Treasury, A Comprehensive Strategy for Reducing the TAx GAp 5 (2006) [hereinafter A Comprehensive Strategy]; Olson, Tax Fairness, supra note 128, at 1.

156 Trends in Complance 2007, supra note 145, at 1-2.

157 U.S. Dep't of the Treasury, FY 2011 Budget in Brief 4-5, 66 (2010). 
enforcement initiatives are aimed at international noncompliance. ${ }^{158}$ Noncompliance by high-income taxpayers and the domestic means of income shifting do not even warrant separate discussion. ${ }^{159}$ Although there is an awareness of the importance of high-income taxpayers' returns, "where a greater amount of misreported taxes are more likely to occur," those with over $\$ 1$ million of income have actually experienced a decrease in their likelihood of audit. ${ }^{160}$

It is an inescapable fact that policing tax avoidance costs money, regardless of the tools the IRS uses, but the IRS has developed lower-cost alternatives. ${ }^{161}$ Not only does the IRS engage in traditional, costly, in-person audits, it is increasingly using correspondence audits that involve sending taxpayers notices and asking them to self-correct. ${ }^{162}$ For example, face-to-face audits increased 25 percent from 2002 to 2005 while correspondence examinations increased by 170 percent. ${ }^{163}$ By 2009 , over 81 percent of audits of individuals and 71 percent of all audits were conducted by correspondence. ${ }^{164}$ This is more than the 67 percent conducted by correspondence in 2005, when 54 percent of the examinations of returns involved business income, where it is easier for taxpayers to avoid tax. ${ }^{165}$ These returns are the source of more than half of the underreporting in the tax gap. ${ }^{166}$

The increased use of correspondence examinations is problematic because there is a limit to the avoidance that can be detected. ${ }^{167}$ The IRS currently

\footnotetext{
158 Id. at 69.

159 See, e.g., id. at 69-76.

160 IRS Oversight Bd., Annual Report 2008, supra note 137, at 14. That was still almost double the audit rate for taxpayers with income of $\$ 200,000$ or more, and more than six times higher than for those with less than $\$ 200,000$. Id .

161 In 1991, the average tax cost for an audit was $\$ 1,300$, but its average yield was $\$ 71,000$. The average cost of a criminal conviction for tax evasion was $\$ 103,000$, and the average return in revenue was $\$ 1.7$ million per conviction. Max B. Sawicky, Do-It-Yourself Tax Cuts, in Bridging the Tax Gap: Addressing the Crisis in Federal Tax Adminstration 1, 13-4 (Max. B. Sawicky ed., 2005).

162 IRS Strategic Plan, supra note 129, at 20. To use its resources more effectively, the IRS began a new sampling program to improve its targeting of returns for examination. Internal Revenue Serv., Dep't of the Treasury, Report to Congress: IRS Tax ComPliance Activities 12 (2003). The National Research Program is analyzing individual returns for 2006, 2007, and 2008. U.S. Dep't of the Treasury, FY 2010 Budget in Brief 68 (2009). There remain many areas that need to be studied to target current taxpayer avoidance, particularly the forms of avoidance likely to be used for income shifting. The IRS last studied partnership returns in 1981, when it received 1,467,282 such returns, and now it receives 2,133,670 returns annually; last studied 1,566,000 fiduciary returns in 1975, and now receives 3,868,101; and last studied $653,600 \mathrm{~S}$ corporation returns in 1984 , and now receives 2,887,100. Robert E. Brown \& Mark J. Mazur, The National Research Program: Measuring Taxpayer Compliance Comprehensively, 51 U. Kan. L. Rev. 1255, 1264 (2003). 163 Treasury Inspector Gen. For Tax Admin., While Examinations of High-Income Taxpayers Have Increased, the Impact on Compliance May Be Limited 2 (2006); Olson, Tax Fairness, supra note 128, at 6. While auditing one of sixty-four high-income taxpayers, the IRS is auditing one of forty-one returns claiming an EITC. U.S. GEN. Accounting Office, IRS Audit Rates: Rate for Individual Taxpayers Has Declined but EFFect on Compliance Is Unknown 8 (2001).

164 Trends in Compliance 2009, supra note 139, at 9-10.

165 Treasury Inspector Gen. for Tax Admin., supra note 163, at 2.

166 Id. at 4.

167 Id. at 2; A Comprehensive Strategy, supra note 155, at 9.
} 
receives from third parties millions of statements as to amounts paid by and to taxpayers and then computer-matches this information with returns. This information reporting and income matching cannot discern income that is never reported on an information return. ${ }^{168}$ The IRS has already witnessed this in its studies of underreporting. Reporting compliance is about 99 percent for wages subject to withholding, 96 percent for income such as interest and dividends subject to third-party information reporting, but only a little more than 40 percent for self-employment income that is not subject to third-party reporting. ${ }^{169}$

Facially valid avoidance devices like income-shifting arrangements are similarly difficult to detect, much less investigate, through information matching. ${ }^{170}$ Thus, the low-cost enforcement tools currently available will be unable to stem the potential tide of inter-spousal tax avoidance. One study found that less than 1 percent of returns with complex schedules are referred to revenue agents, as all complex returns are required to be. ${ }^{171}$ Without the referral, income shifting cannot be investigated. As the National Taxpayer Advocate has warned, "There are indications that the IRS is using correspondence examinations to accomplish work that is better reserved for interviews or field audits." 172

That correspondence audits cannot ferret out certain kinds of tax avoidance benefits some taxpayers more than others. For example, the proportion of income that cannot be verified by document matching is 10 percent of the income of those reporting less than $\$ 100,000$, compared to 35 percent for taxpayers reporting more than $\$ 100,000 .{ }^{173}$ For people in the top 0.01 percent of taxable incomes, interest, dividends, and realized capital gains, all from income-producing property that presumably can be shifted, accounted for 55.9 percent of their incomes. ${ }^{174}$ Wages, income that is difficult to shift, composed

168 Johnson, supra note 16, at 1018; TREASURy InSPECtOR Gen. FOR TAX Admin., supra note 163, at 2; Charles Rossotti, IRS Says Grassley Is Right About Taxpayer Review, Audit Rates, Tax Notes Today, Mar. 28, 2001. For a discussion of new information-reporting requirements scheduled to take effect in 2011, see generally Leandra Lederman, Reducing Information Gaps to Reduce the Tax Gap: When Is Information Reporting Warranted?, 78 Fordham L. Rev. 1733, 1733 (2010). Although the current economic crisis might have reduced the percentages, income subject to third-party information reporting fell from 91.3 percent in 1980 to 81.6 percent in 2000 because of a growth in capital gains and partnership and small business income. Rossotti, supra.

169 Olson, Tax Gap, supra note 152, at 2; Olson, Tax Fairness, supra note 128, at 24.

170 In-person audits also raise more tax revenue. In-person examinations usually result in assessments of $\$ 9,540$, while document matching only produces $\$ 1,506$. Rossotti, supra note 168 .

171 U.S. Gen. Accounting Office, IRS Audit Rates, Weaknesses in Selecting and Conducting Correspondence Audits 6 (1999).

172 Olson, Tax Fairness, supra note 128, at 8.

173 Rossotti, supra note 168. Moreover, 91 percent of taxpayers reporting income over $\$ 100,000$ itemize their deductions compared with 26 percent of those under $\$ 100,000$. Id. 174 An additional 15.2 percent was other business income. Cong. Budget OfFice, Historical Effective Tax Rates, 1979 to 2005: Supplement with Additional Data on Sources of Income ANd High-Income Households 3 (2008) [hereinafter Historical EfFective Tax Rates]. The study shows that effective individual income tax rates decline from a high of 20.7 percent for the top 99.5 to 99.9 percent down to 17 percent for the top 0.01 percent of the population. Id. at tbls. $1 \& 2$. The CBO also recognized the ease with which spouses switch ownership of assets for state tax purposes in states that tax spouses 
only 13.2 percent of their total incomes. ${ }^{175}$ As before 1948 , there are plenty of tax advisors who are willing to help these taxpayers exploit their opportunities. ${ }^{176}$ According to the IRS, private tax professionals outnumber IRS employees by ten to one. ${ }^{177}$

This high-end tax evasion is detrimental to the tax system both because of the amount of revenue it costs the federal government directly and because of its impact on noncompliance from all income groups. ${ }^{178}$ When people believe that others have manipulated the Internal Revenue Code, normally compliant taxpayers are tempted to do so as well. ${ }^{179}$ There is already a sense that wealthy taxpayers do not foot their share of the tax burden and that the IRS does nothing to police their tax avoidance, and so only fools willingly pay the taxes they owe. Some estimate that the underreporting of income now reaches 25 percent of the population and accounts for 40 percent of the federal deficit. ${ }^{180}$ So, while the IRS Oversight Board's 2010 Taxpayer Attitude Survey indicates that 87 percent of taxpayers think it is "not at all" acceptable to cheat on taxes, ${ }^{181}$ the number who "completely agree" that "[i]t is every American's civic duty to pay their fair share of taxes" is only 69 percent and those who "completely agree" that "everyone who cheats on their taxes should be held accountable" was only 69 percent. ${ }^{182}$

Thus, the implications of income shifting extend well beyond the few who choose to engage in this behavior. The U.S. government has always feared that the income tax would produce a nation of liars. Congressman Justin Morrill, worried about progressive taxation in 1864, suggested "that people who are taxed unequally on their incomes regard themselves as being unjustly treated, and seek all manner of ways and means to evade it." 183 But the larger problem with income-shifting tax avoidance is that individual filing will aggravate differences between honest taxpayers who know the loopholes and those who do

individually. Cong. Budget Office, For Better or For Worse: Marriage and the Federal Income Tax 62 app. B (1997) [hereinafter For Better or For Worse].

175 Historical Effective Tax Rates, supra note 174, at tbl.4.

176 See, e.g., Susan Cleary Morse, Stewart Karlinksy \& Joseph Bankman, Cash Businesses and Tax Evasion, 20 StAn. L. \& PoL'y Rev. 37, 57-61 (2009); see also, supra notes 60 and 67. Much of the tax that is determined to be due from high-income taxpayers is never collected. In 2006, the IRS either abated or could not collect 86 percent of this group's audit assessments. Of the $\$ 2.1$ billion assessed on them through correspondence examination in 2004, \$1.4 billion (66 percent) was attributable to taxpayers who did not respond to the correspondence. Treasury Inspector Gen. for TAX Admin., supra note 163, at 2; Olson, Tax Fairness, supra note 128, at 9.

177 IRS STRATEGIC PLAN, supra note 129, at 16.

178 See Steven M. Sheffrin \& Robert K. Triest, Can Brute Deterrence Backfire? Perceptions and Attitudes in Compliance, in Why People Pay Taxes: Tax Compliance and ENFORCEMENT 193, 194 (Joel Slemrod ed., 1992).

179 For a good discussion and additional materials, see Leandra Lederman, The Interplay Between Norms and Enforcement in Tax Compliance, 64 Оhіо State L.J. 1453, 1497-99 (2003).

180 Erich Kirchler, The Economic Psychology of Tax Behaviour 23 (2007).

181 This is the highest level since the survey began in 2002. IRS Oversight BD., 2010

Taxpayer Attitude Survey 2 (2011).

182 Id. at 3.

183 Cong. Globe, 38th Cong., 1st Sess. 1876 (1864). 
not, in addition to the differences between honest and dishonest taxpayers. Scholars warn, "Complexity favors the gambler at each step in the game."184

To deal with these gambles would require new laws, only further increasing the Code's complexity and opportunity for abuse. Before 1948, those engaged in tax avoidance exploited tax rules, particularly those rules governing partnerships and trusts. This exploitation, and the resulting pressure on the system, was reduced by the adoption of income-splitting joint filing. If individual filing is re-adopted as many scholars currently propose, those pressures will again erupt. ${ }^{185}$ If Congress and the Treasury Department were to shut down non-substantive income shifting of the kind that existed before 1948, despite relative taxpayer apathy and the need for department funding, it would require significant changes to these laws.

We must worry that changes initiated for this purpose will simply repeat the earlier cycle. A mere twenty years after the enactment of the modern income tax, Justice Cardozo noted that "[o]ne can read in the revisions of the revenue acts the record of the Government's endeavor to keep pace with the fertility of invention whereby taxpayers had contrived to keep the larger benefits of ownership and be relieved of the attendant burdens." ${ }^{186}$ Responding to the same incentives of the last century, laws to police income-shifting devices will further add to the complexity of the Code.

In light of these complications, when Congress considers changes to the tax system, it should take into account the IRS's and taxpayers' logistical and financial constraints as well as the tax avoidance incentives it is creating. ${ }^{187}$

184 Edward J. McCaffery, The Holy Grail of Tax Simplification, 1990 WIs. L. Rev. 1267, 1290 (1990); see also IRS Oversight BD., Annual Report 2008, supra note 137, at 4; A COMPREHENSIVE STRATEgy, supra note 155 , at 3.

185 "The IRS estimates that $\$ 1.1$ trillion in income goes through passthrough entities. The three most common are trusts, partnerships, and S corporations; their use has been increasing ... . [T]rust filings [have] risen 12 percent since 1995, partnerships are up to 33 percent, and S corporation 35 percent . . .." George Guttman, Why Did the K-1 Matching Program Go Awry?, 97 TAx Notes 736, 736 (2002). The "[a]pplication of the substance-over-form doctrine to family limited partnerships merits special consideration," but, as scholar James Repetti has warned, the problem will not work as a practical matter. James R. Repetti, Minority Discounts: The Alchemy in Estate and Gift Taxation, 50 TAx L. Rev. 415, 452 (1995). For reasons mentioned above, recent efforts to apply information matching to passthrough entities will not significantly improve compliance when dealing with family entities. See also Michael P. Dolan, IRS Resumes K-1 Matching Program, 34 Tax Advisor 232, 232 (2003); Treasury Inspector Gen. for Tax Admin., The Schedule K-1 Matching Program Has Been Improved, but More Can Be Done to Increase Its Effectiveness 1 (2006); U.S. Gov't Accountability Office, GAO-04-1040, Tax Administration: IRS Should Take Steps to Improve the Accuracy of Schedule K-1 Data 25 (2004). Rossotti argued that every fifth dollar of partnership income was not reported, for a tax loss as high as $\$ 7$ to $\$ 64$ billion. Johnston, supra note 147 ; TREASUry InSPECTOR GEN. FOR TAX AdMIN., supra note 185.

186 Burnet v. Wells, 289 U.S. 670, 675-76 (1933).

187 Leslie Book has argued that "policymakers concerned with cheating should pay closer attention to structural incentives and the relative ease in which individuals' non-compliance falls outside the light of day." Leslie Book, Freakonomics and the Tax Gap: An Applied Perspective, 56 Am. U. L. Rev. 1163, 1167 (2007); see, e.g., Boris Bittker, Federal Taxation-Then and Now, Woodworth Lecture (Nov. 1, 1996), in 23 Oнго N.U. L. Rev. 617, 625-26 (1997); Johnson, supra note 16, at 1039-44; Leandra Lederman, Statutory Speed Bumps: The Roles Third Parties Play in Tax Compliance, 60 Stan. L. Rev. 695 (2007); 
An unintended consequence of individual filing would be that the financially strapped IRS is left struggling to contain tax avoidance or is forced to abdicate control over spousal income shifting. ${ }^{188}$ In the post-World War II era, there are simply too many taxpayers for the government to make a meaningful attempt at enforcing this type of system. Removing the current structural restrictions on income-shifting tax avoidance would therefore shift the burden of the tax system onto those who only earn wages, those who choose to comply with the tax law, and those few who are targeted for audit. Before we open this Pandora's box, we must have some sense and acceptance of what is inside.

\section{The Goal: Defining the Ability to Pay Taxes}

There is more than just government revenue and statistics on tax compliance at stake when married couples shift income from spouses in higher tax brackets to those in lower ones and thereby reduce their collective tax obligations. Income-shifting devices are a particular threat to progressive taxation: they enable certain categories of taxpayers, but not all taxpayers, to reduce their effective taxation. As a result, similarly situated taxpayers are not treated similarly; some are rewarded with tax reduction because of their tax planning. When evaluating the most equitable way to impose the income tax, the federal government should ignore legal distinctions that obfuscate taxpayers' abilities to pay. With respect to the issue of the tax unit, this means the government must look at the total income of married couples, because it is their combined incomes that best describes their collective ability to pay taxes and not their individual incomes which might more easily be adjusted through tax planning. ${ }^{189}$

The choice of a tax unit properly hinges on these questions of equity because there is no option that will satisfy the self-interests of all taxpayers in all situations. ${ }^{190}$ The use of a progressive bracket structure in a system with single individuals and one- and two-earner couples will necessarily result in at least one group feeling disadvantaged relative to the others. As long as different taxpayers have different marital and economic circumstances, it will be impossible to create a system that is perceived of as fair without a theoretically grounded basis for determining the appropriate tax unit.

McCaffery, supra note 184, at 1283. That some states allow individual filing does not mean that its administrative costs will not be formidable at the national level. The relative reach and breadth of the two levels of tax differ considerably, enough to alter incentives. See the CBO's finding, supra note 174.

188 The cost of the ability to shift income was recognized, but dismissed, in Note, The Case for Mandatory Separate Filing by Married Persons, 91 YALE L.J. 363, 378-81 (1981).

189 If any change is made to the tax unit, it should be in the opposite direction, to broaden rather than narrow the tax unit. Although not all families operate as units, individual choices determine the extent to which they operate cohesively.

190 The federal income tax system has historically had competing objectives-treating all taxpayers in the same economic position the same way regardless of their marital status (i.e., horizontal equity which is in itself difficult to define, let alone achieve), and taxing everyone according to their ability to pay (i.e., progressive taxation). The system cannot accomplish these goals at the same time. Bittker, supra note 10, at 1396-97. 
It is possible, however, to determine the best tax unit by examining how the income tax means to tax people. With the 1913 income tax, the nation's leaders adopted progressive income taxation on the theory that those with more income are better able to pay more in taxes. ${ }^{191}$ Today, scholars recognize that "[o]ur income tax is premised on the principle that the burdens of tax ought to be distributed according to relative ability to pay." ${ }^{192}$ Leading casebooks state this conclusion without much debate. ${ }^{193}$ Many in Congress similarly believe that "[o]ne of the basic tenets of tax policy is that an accurate measurement of ability to pay taxes is essential to tax fairness." 194

What scholars and politicians differ on, and what creates difficulty for applying the standard, is determining what ability to pay means in practice. ${ }^{195}$ This Article does not answer the question of how to define the ability to pay taxes; instead, it reframes the question as whose income should be included in that determination. ${ }^{196}$ Depending on what the government determines to be the taxable unit (whether individuals or couples), it will arrive at very different amounts of taxable income even when imposing the same tax statutes. The calculation of the ability to pay, on whatever it is based, should be applied to the larger unit.

Henry Simons once warned, "[I]f we are to tax different economic classes in a widely different manner, we must devise equitable techniques for defining classes and for locating taxpayers in the proper classes." 197 The justness of this

191 See John D. Buenker, The Income Tax and the Progressive Era in Modern AmericAn History 43 (A Garland Ser., Robert E. Burke \& Frank Freidel eds., 1985); Harold M. Groves, Tax Philosophers: Two Hundred Years of Thought in Great Britain and the United States 13-88 (Donald J. Curran ed., 1974); Richard A. Musgrave, The Theory of Public Finance: A Study in Public Economy 61-115 (1959); Edwin R. A. Seligman, Essays in TaXation 340 (9th ed. 1921); William E. Borah, Income-Tax Amendment, 191 N. Am. Rev. 755 (1910); Edwin R. A. Seligman, Progressive Taxation in Theory and Practice, 9 Am. Econ. Ass'N. Q. 1 (1908); John F. Witte, Tax Philosophy and Income Distribution, in Value Judgment and Income Distribution 340 (Robert P. Solo \& Charles W. Anderson eds., 1981).

192 Kornhauser, supra note 10, at 92.

193 See, e.g., J. Martin Burke \& Michael K. Friel, Taxation of Individual Income 4 (8th ed. 2007); William A. Klein, Joseph Bankman \& Daniel N. Shaviro, Federal Income Taxation 6-7 (14th ed. 2006); Richard Schmalbeck \& Lawrence Zelenak, Federal Income Taxation 21-4 (2d ed. 2007).

194 Theodore P. Seto \& Sande L. Buhai, Tax and Disability: Ability to Pay and the Taxation of Difference, 154 U. PA. L. Rev. 1053, 1073 n.96 (2006) (quoting Staff of Joint Comm. on Taxation, 108th Cong., Description of Revenue Provisions Contained in the President's Fiscal Year 2005 Budget Proposal 8 (Comm. Print 2004)) (regarding child tax credit).

195 For example, Henry Simons argued that saying you want to apply this standard, "which cannot be conceived quantitatively or defined in terms of any procedure or measurement," does not explain why you support it or how much tax will be justified. Henry C. Simons, Personal Income Taxation: The Definition of Income as a Problem of Fiscal Policy 17 (1938). For a review of the history of the ability to pay, see Joseph M. Dodge, Theories of Tax Justice: Ruminations on the Benefit, Partnership, and Ability-to-Pay Principles, 58 Tax L. Rev. 399 (2005); Stephen Utz, Ability to Pay, 23 Whittier L. Rev. 867, 869-70 (2002).

196 Although I agree that there is no perfect measure of taxpayers' ability to pay taxes, that does not preclude attempts to create workable measures that move us closer to the goal.

197 Simons, supra note 195 , at 30. 
classification is important because it judges the relative fairness of the tax regime for different taxpayers. Recognizing this classification as the fundamental question of the tax unit, it becomes clear that taxes should not be viewed as pitting the taxpayer against the government but as taxpayers against each other. In order to determine how much various individuals can pay, the government must judge them vis-à-vis other taxpayers. For example, if Person (or Couple) A does not have to pay tax because of favorable tax provisions or successful tax avoidance then, all other things being equal, Person (or Couple) $\mathrm{B}$ who does pay the tax is paying relatively more. It is the relative and not absolute tax burden that matters for this purpose.

For many critics of the joint return, the objective is to change the comparison from between families or units to between individuals. ${ }^{198}$ They seek to break apart the determination of how much a unit can pay in order to improve incentives for part of the unit. However, regardless of whether one spouse in a marriage might be in a relatively worse economic situation than another spouse in another marriage, couples with more income can afford to pay more in taxes than those with less. As an illustration, assume there are no costs of producing income: if Couple A-B has $\$ 50,000$ in income, all earned by A, and Couple C$\mathrm{D}$ has $\$ 50,000$, earned $\$ 25,000$ by $\mathrm{C}$ and $\$ 25,000$ by $\mathrm{D}$, both couples have the same relative ability to pay taxes.

\begin{tabular}{|l|l|l|}
\hline A earns $\$ 50,000$ & B earns $\$ 0$ & Couple A-B earns $\$ 50,000$ \\
\hline C earns $\$ 25,000$ & D earns $\$ 25,000$ & Couple C-D earns $\$ 50,000$ \\
\hline
\end{tabular}

Both couples have the same expenses (if one removes the additional cost of earning the second income) for providing for two people. ${ }^{199}$

Therefore, accepting a unity within marriage for the calculation of tax obligations is the only fair way to judge as between units. Those units with more money, however the money is subdivided, have a greater ability to pay taxes than those with less. Although individual filing might appear to put married couples and single taxpayers on equal footing, it ignores real differences in their abilities to pay taxes because of the variations in combined wealth different couples might enjoy. If you accept the principle of progressive taxation, Couple C-D with $\$ 50,000$ of income can afford to pay more in taxes than C or $\mathrm{D}$, each alone with $\$ 25,000$ of income. How much more C-D can pay as a couple is the subject of another debate. ${ }^{200}$ And A, earning $\$ 50,000$ before she marries, is in a different economic position after marriage. In addition to these economic realities, the ability to engage in tax planning through income shifting gives some married couples, in this example Couple A-B, opportunities that other taxpayers, Couple C-D or any of them as single individuals, simply do

198 See, e.g., Christian, supra note 10, at 305-48.

199 Deciding that couples are the appropriate unit for determining how much income a couple has does not determine the rate that should be applied to them relative to single taxpayers. The government might decide to tax couples at higher or lower rates than single taxpayers, but that is a question we can only meaningfully broach once the taxable unit has been agreed upon.

200 I realize there is some debate about the extent of economies of scale within households, but that goes to proper relative tax brackets between single and married taxpayers. 
not have. Even if it never chooses to shift income, Couple A-B has a choice that low-income couples or single taxpayers do not have. ${ }^{201}$ Similarly, if two unmarried individuals pool their resources, the frequent example being adult siblings, they do not have a family court automatically allocating pooled wealth upon the termination of the relationship. For married couples, divorce proceedings increasingly require an equal division of accumulated assets. ${ }^{202}$

The revival of a consideration of the ability to pay is needed in family taxation because there has been a shift from looking at the various taxable units' abilities to pay to focusing on efficiency and how the joint filing system influences the way couples behave. ${ }^{203}$ First, there are claims that the joint return discourages marriage and, second, that it discourages wives from entering the paid labor force. ${ }^{204}$ These issues are often discussed as equity concerns, in that they involve discrimination against women, but the underlying objective is to incentivize certain behavior, namely marriage and wives' paid labor. Thus, the debate is not about efficiency in the sense that the government should minimize tax-induced distortions of individuals' decisions but, rather, that the distortions should be ones we perceive as more equitable. We should not ignore that regardless of which tax unit the government adopts, some behaviors will receive greater economic rewards than will others. ${ }^{205}$

There is truth to the claim that behavior is influenced by taxes. For example, there is evidence that taxes have a small but statistically significant effect on the decision whether to marry. ${ }^{206}$ There rightly is a concern that the disincentive might be particularly strong for lower-income taxpayers because married couples are more likely to be pushed to the phase-out level of the EITC,

201 Martha Minow suggests that a functional approach to the family might lead to its abuse. Martha Minow, Redefining Families: Who's In and Who's Out?, 62 U. Colo. L. Rev. 269, 276-78 (1991). Similarly worried about abuse, Robert S. McIntyre and Michael J. McIntyre suggest that couples have the option to divorce and, through alimony payments, to reduce their taxes. Robert S. McIntyre \& Michael J. McIntyre, Fixing the "Marriage Penalty" Problem, 33 VAL. U. L. Rev. 907, 930 (1999).

202 Alicia Brokars Kelly, Money Matters in Marriage: Unmasking Interdependence in Ongoing Spousal Economic Relations, 47 U. LouisviLle L. Rev. 113, 115 \& n.165 (2008). 203 Compare this to the debates discussed in Part II.

204 See infra notes 206 and 213.

205 If one accepts the secondary earner bias, the alternative creates an economic incentive for married women to work, even at otherwise unwanted jobs, because their first dollars would be taxed in low brackets. This is a distortion in its own right. It might be more equitable than the economic push for them to stay at home, but it should be debated as such. 206 See James Alm \& Leslie A. Whittington, Does the Income Tax Affect Marital Decisions? 48 NAT'L TAX J. 565, 571 (1995); James Alm \& Leslie A. Whittington, Income Taxes and the Marriage Decision, 27 Applied Econ. 25, $25-27$ (1995); James Alm \& Leslie A. Whittington, Income Taxes and the Timing of Marital Decisions, 64 J. Pub. Econ. 219, 21920 (1997); Leslie A. Whittington \& James Alm, 'Til Death or Taxes Do Us Part: The Effect of Income Taxation on Divorce, 32 J. Hum Resources 388 (1997). But see Stacy DickertConlin, Taxes and Transfers: Their Effects on the Decision to End a Marriage, 73 J. PuB. ECon. 217, 218 (1999); Alexander M. G. Gelardi, The Influence of Tax Law Changes on the Timing of Marriages: A Two-Country Analysis, 49 NAT'L TAx J. 17, 25 (1996); Saul D. Hoffman \& Greg J. Duncan, The Effect of Incomes, Wages, and AFDC Benefits on Marital Disruption, 30 J. Hum. Resources 19, 38 (1995); Marjorie B. McElroy, The Empirical Content of Nash-Bargained Household Behavior, 25 J. Hum. Resources 559, 578-79 (1990); David L. Sjoquist \& Mary Beth Walker, The Marriage Tax and the Rate and Timing of Marriage, 48 NAT'L TAX J. 547, 556 (1995). 
despite changes made in 2001 to expand the phase-out range. ${ }^{207}$ Some studies show that EITC families do make choices in order to minimize marriage penalties. ${ }^{208}$

There is less evidence of the second concern that wives do not enter the paid labor force because of joint taxation. The concern is that when filing a joint return, the spouse who earns the lesser income, more frequently the wife, is psychologically taxed at higher rates than the primary earner. This is because the primary earner is considered to earn a couple's first dollar, thereby producing the income taxed in the couple's lowest tax brackets. The secondary earner's first dollar of income is therefore taxed in the primary earner's top tax bracket. This feminist critique was made famous in a 1971 article by Grace Ganz Blumberg, and it has support from research that finds that married women's participation in the labor market tends to be more sensitive to taxes than is men's participation. ${ }^{209}$ Because wives' labor is more responsive to outside forces such as wages or childcare responsibilities, or as economists would say is more elastic, than the labor of their husbands, wives can be more easily induced to enter the market. If wives are, in fact, persuaded to enter the paid labor force, there would be less net utility loss from the increased production than if their husbands simply work more because it costs society less to get wives to do so. ${ }^{210}$ Relying on optimal tax theory, Edward McCaffery not only wants a return to individual filing but also preferential tax rates for women to procure this result. ${ }^{211}$

However, not everybody agrees that wives should be categorized as secondary wage earners. Dorothy Brown, for example, argues that mainly upperincome, white families hold this categorization of wives' labor. ${ }^{212}$ Studies show that even for this group, the view is less true today than it was in earlier periods. Married women's wage elasticity decreased steadily throughout the 1980s and 1990s, and from 1980 to 2000 it declined by up to 56 percent and cross-wage elasticity (or the responsiveness of wives' work to changes in their

207 The Economic Growth and Tax Relief Reconciliation Act of 2001, Pub. L. No. 107-16, $\S 303,115$ Stat. 38, 55-57 (2001).

208 See Dorothy A. Brown, The Tax Treatment of Children: Separate But Unequal, 54 EMORY L.J. 755, 826-28, 832 (2005); Stacy Dickert-Conlin \& Scott Houser, EITC and Marriage, 55 NAT'L TAX J. 25, 26 (2002). David T. Ellwood finds some changes in behavior, but finds them "small and ambiguous." David T. Ellwood, The Impact of the Earned Income Tax Credit and Social Policy Reforms on Work, Marriage, and Living Arrangements, 53 NAT'L TAX J. 1063, 1087-1100 (2000).

209 Blumberg, supra note 10, at 52. A good survey of this literature is available at MCCAFFERY, supra note 10, at 179-84.

210 A 1997 CBO report found that joint taxation leads the lower-earning spouse to work between 4 and 7 percent less than he or she otherwise would, but that this reduces family earnings by only 0.7 and 1.2 percent because the higher-earning spouse works more. FOR BETTER OR FOR WORSE, supra note 174, at 12.

211 Edward J. McCaffery, Taxation and the Family: A Fresh Look at Behavioral Gender Biases in the Code, 40 UCLA L. Rev. 983, 1035-46, 1060 (1993). While McCaffery has warned that the income-splitting joint return might make the traditional single-earner family self-perpetuating, wives are increasingly entering the paid labor force even in the face of negative tax consequences. Id. at 1000.

212 Dorothy A. Brown, Race, Class, and Gender Essentialism in Tax Literature: The Joint Return, 54 Wash. \& Lee L. Rev. 1469, 1508-11 (1997). 
husbands' wage rates) decreased up to 47 percent. $^{213}$ As of $2007,53.1$ percent of all married couples had two earners, and increasingly this is true for wealthier couples. 214

This is not to dismiss the real economic costs associated with having two, as opposed to one, wage earners in a marriage. ${ }^{215}$ From transportation costs and meals outside the home to the loss of imputed income, two earners spend more than one earner in order to earn the same income. As critics correctly point out, the existing system does not reflect these additional costs. ${ }^{216}$ This author strongly supports a two-earner deduction so that these costs are included in the determination of the amount that families can afford to pay in taxes. ${ }^{217}$ Nevertheless, regardless of whether Congress accedes to this wisdom, these additional costs do not disprove that couples' collective incomes should be the basis for judging how much they are able to pay. ${ }^{218}$ These are two fundamen-

213 See Cicconi, supra note 10, at 263-64; see also Francine D. Blau \& Lawrence M. Kahn, Changes in the Labor Supply Behavior of Married Women: 1980-2000, 25 J. LAB. Econ. 393, 395 (2007); Bradley T. Heim, The Incredible Shrinking Elasticities: Married Female Labor Supply, 1978-2002, 42 J. Hum. Resources 881, 905 (2007); Chinhui Juhn \& Kevin M. Murphy, Wage Inequality and Female Labor Supply, 15 J. LAB. Econ. 72, 91 (1997); Thomas A. Mroz, The Sensitivity of an Empirical Model of Married Women's Hours of Work to Economic and Statistical Assumptions, 55 Econometrica 765, 795 (1987); Nancy C. Staudt, Taxing Housework, 84 Geo. L.J. 1571, 1600 (1996). But see Paul J. Devereux, Changes in Relative Wages and Family Labor Supply, 39 J. Hum. ResourCes 696, 717 (2004); Claudia Goldin, The Quiet Revolution that Transformed Women's Employment, Education, and Family, 96 Am. Econ. Rev. 1, 12 (2006); Robert K. Triest, The Effect of Income Taxation on Labor Supply in the United States, 25 J. Hum. Resources 491, 513 (1990). Nada Eissa and Hilary Williamson Hoynes found that the expansion of EITC means 2 percent fewer wives are likely to enter the labor force. Nada Eissa \& Hilary Williamson Hoynes, Taxes and the Labor Market Participation of Married Couples: The Earned Income Tax Credit, 88 J. Pub. Econ. 1931, 1954 (2004).

214 U.S. Census Bureau, Percent of Married-Couple Families With Both Husband AND Wife IN THE LABOR ForCE (2007), http://factfinder.census.gov/servlet/ThematicMap FramesetServlet?_bm=y\&-geo_id=01000US\&-tm_name=ACS_2007_3YR_G00_M00661\& -ds_name (last visited Jan. 29, 2011). The growth in single-earner families is the result of more single-parent households. These families are currently assisted by the head of household status that allows them more advantageous tax brackets than are available to single taxpayers, a benefit they will likely lose if the nation adopts individual filing.

215 See Sandra L. Hanson \&Theodora Ooms, The Economic Costs and Rewards of Two Earner, Two-Parent Families, 53 J. Marriage \& FAM. 622, 623 (1991). One-earner families also have a greater ability to pay taxes because they have the imputed income of the nonwage earning spouse. One could argue that a second-best solution is to adopt individual filing and impose greater tax burdens on these families. However, individual filing would only succeed if it does, in fact, impose a greater tax burden on those families.

216 Individual filing only addresses these costs through the reduction in the tax rate applicable to second earners. As a result, the only secondary earners aided by individual filing will be those in higher rate brackets. For those taxpayers, this might be a disproportionately large reduction in taxes to the costs incurred.

217 The best form of such a two-earner deduction is left for discussion in a future article.

218 It is also not constitutionally required. One court ruled,

Congress could assume reasonably that where spouses are living together, the cost of maintaining the household is shared between them to the extent of their respective resources. That this assumption should prove erroneous in petitioner's situation is unfortunate, but immaterial to the constitutional validity of [the tax sections in dispute].

Cash v. Comm'r, 580 F.2d 152, 155 (5th Cir. 1978). 
tally different issues before Congress, and the desire to offset the costs that discourage wives from working should not affect considerations of the unit for judging the ability to pay taxes. ${ }^{219}$

Moreover, with respect to both of these concerns, it should not be the province of the tax system to police marital choices or behavior within marriage. It is inefficient and inequitable for Congress to extend a means of tax avoidance in the hopes of procuring a more balanced division of assets or of labor, particularly because the results might not always be more equitable. We must expect that couples will learn how to game the system and will exploit the system to their own pecuniary advantage. They did so before 1948 and they will again. Some couples who would not marry will do so for tax savings and wealthy men's wives will gain the EITC for their employment at their husbands' businesses, despite their lifestyle or lack of economic need. The equitableness of these consequences must be included in these deliberations.

Instead of policing individual behavior, the government should think of married couples as a functional unit. If government aid, from food stamps to tax credits, looks to the combined incomes of husband and wife to determine their level of need, it makes sense that the government look at the same sources to determine their ability to pay taxes. ${ }^{220}$ It does not matter for this purpose that the shape of marital unions has changed. Although marriage is less the patriarchal hierarchy than it was in 1948, and for that the author is personally thankful, that change does not negate the fact that focusing on couples as a unit remains the best standard for judging their relative economic worth compared to other taxpayers.

Nonetheless, some scholars decry this result, questioning whether spouses pool their income or function as a unit. ${ }^{221}$ Couples, they argue, do not share, combine incomes, or work for their common good. Instead, marriage is composed of isolated individuals who marry and remain the same isolated individuals as they were before. Even further than Justice Roberts was willing to go in Hoeper, they argue that marriage today changes nothing. ${ }^{222}$ Research on the extent to which couples pool their incomes remains inconclusive, but common sense suggests that most married couples must pool their resources in order to survive because they earn so little collectively. ${ }^{223}$ One recent study, in fact,

219 Theoretically, the government should provide a deduction for the costs of each spouse earning income relative to receiving the income from investments, but this is not politically feasible. Moreover, the tax system should provide reasonable exemption rates that reflect the costs of supporting each family member but, again, this is unlikely.

220 This issue was raised by at least one pre-war practitioner. Herman T. Reiling, Taxing the Income of the Husband and Wife, 14 TAx MAG. 198, 198 (1935).

221 See, e.g., Alstott, supra note 10, at 2027-28; Kornhauser, supra note 10, at 63, 77-78. But see Michael J. McIntyre, Individual Filing in the Personal Income Tax: Prolegomena to Future Discussion, 58 N.C. L. Rev. 469, 470 (1980); Zelenak, supra note 10, at 351.

222 See case cited supra note 74.

223 See, e.g., Philip Blumstein \& Pepper Schwartz, American Couples: Money, Work, SEx 94-109 (1983); Geoffrey Lancaster \& Ranjan Ray, Tests of Income Pooling on Household Budget Data: The Australian Evidence, Austl. ECon. PAPERs, Mar. 2002, at 99, 11213; Shelly J. Lundberg, Robert A. Pollak \& Terence J. Wales, Do Husbands and Wives Pool Their Resources?: Evidence from the United Kingdom Child Benefit, 32 J. Hum. Resources 463, 464 (1997); Zelenak, supra note 10, at 348-55. Arguably, both individual and joint 
suggests that 82.6 percent of American married couples commingle their incomes. $^{224}$

Regardless of the ultimate answers to whether couples pool their incomes, it is the wrong question to ask. It is not required that all married couples pool their incomes for spouses to be equitably considered as a group by the government for tax purposes. In many situations, taxpayers are taxed on income because they have control over the enjoyment of that income, even if the control is never exercised. ${ }^{225}$ An analogous situation exists between spouses as they decide whether or not to pool their incomes. ${ }^{226}$ Spouses control whether to share their incomes and a decision to refrain from sharing should not affect their taxability on the collective amount.

The Code is riddled with rules that take for granted that families have economic interests in common and that families are frequently willing to work together to thwart the federal taxing authority. ${ }^{227}$ Congress has enacted hundreds of special rules governing the tax treatment of spouses and children, such as personal exemptions, ${ }^{228}$ the exclusion of Social Security benefits, ${ }^{229}$ the credit for certain household and dependent care expenses, ${ }^{230}$ the earned income tax credit, ${ }^{231}$ and the disallowance of loss deductions for sales between family members, ${ }^{232}$ just to name a few. ${ }^{233}$ Although these rules have evolved along different paths and monitor different family relationships, they each recognize as important the relationship between spouses.

Married couples are seen as cooperative units because the alternative, of seeing them as disparate individuals sharing only social connections, would produce numerous unintended and economically disastrous consequences for many couples. If one spouse has losses and the other has income, should the government not offset the latter's income with the former's losses in calculating the taxes they owe, even if, in a particular case, the spouses choose not to do so? If the question is answered in the negative in order to preserve the

filing are imperfect measures of family and individual economic well-being. Zelenak, supra note 10 , at $351-58$.

224 Only 54.3 percent comingle funds if couples cohabitate. Kristen R. Heimdal \& Sharon K. Houseknecht, Cohabitating and Married Couples' Income Organization: Approaches in Sweden and the United States, 65 J. Marriage \& FAm. 525, 532 (2003).

225 As a basic example, see I.R.C. $§ 674$ (2006) with respect to irrevocable trusts.

226 If scholars agree that spouses who pool their incomes have a greater ability to pay taxes, an individual choice by some not to do so, and not to maximize their ability to pay, arguably should not decrease their tax burdens. On the other hand, the government does not tax people assuming they maximize their taxable income.

227 The tax system has been gradually moving toward including children in the tax unit. Beginning in 2007, pursuant to the "kiddie tax," first introduced in 1986, any unearned income received by a child under nineteen, and a full-time student under twenty-four, is taxed at the parents' highest tax rate. U.S. Troop Readiness, Veterans' Care, Katrina Recovery, and Iraq Accountability Appropriations Act, 2007, Pub. L. No. 110-28, § 8241, 121 Stat. 112, 199 (2007); I.R.C. $\$ 1(\mathrm{~g})$. Although not including this income in the parents' income per se, it does recognize the family as a functioning unit.

228 I.R.C. $\$ 151$.

229 Id. $\$ 86$.

$230 I d . \$ 21$.

231 Id. $\$ 32$.

232 Id. $\$ 267$.

233 See Seto, supra note 14, at 1531. 
independence of each spouse, and the government returns to the individual as the tax unit, harsh tax burdens, and a blatant disregard of the ability to pay taxes, will result for many families.

Inequities would follow not only from the tax rates applied to various groupings of taxpayers but also from other provisions of the Code that would need to be changed. Congress would need to remove privileges currently extended to married couples in order for individual filing to be fair as between taxpayers who do shift income and those who either will not or cannot shift their income. For example, spouses are currently able to give each other any amount of their income or assets without triggering the gift tax. ${ }^{234}$ If we return to individual filing and the federal government does not impose a gift tax on these exchanges, then couples with income-producing assets could reduce their federal income taxes at their discretion and without any cost, making the top tax rates optional for many couples. ${ }^{235}$ The practical result would then be an increase in the relative tax burden of single taxpayers, and couples without shiftable income, such as wages alone, would be disadvantaged relative to the lucky few.

Moreover, in a system with individual filing, spouses should arguably be treated as giving taxable gifts when they spend money on what many see as spousal obligations. As an illustration, not only should individuals lose the deduction currently enjoyed under I.R.C. $\$ 213$ when they pay the medical expenses of their spouses, but they should also be treated as giving taxable gifts. These consequences likely rankle because they are contrary to the idea that couples are, in fact, economic units even if every unit does not function perfectly. Without these harsh consequences, the tax system will inconsistently

234 I.R.C. § 2523. Similarly, spouses can leave assets to each other at death without the estate tax applying. Id. $\S 2056$. Crawford has argued that we should repeal these exemptions. See Bridget J. Crawford, One Flesh, Two Taxpayers: A New Approach to Marriage and Wealth Transfer Taxation, 6 FLA. TAx REv. 757, 760 (2004). The gift tax is currently one of the most weakly enforced parts of our revenue system, and a substantial infusion of money and enforcement resources will be required to police abuse. David Cay Johnston, I.R.S. Sees Increase in Evasion of Taxes on Gifts to Heirs, N.Y. Times, Apr. 2, 2000, at 1, 20; Trends in Compliance 2007, supra note 145, at 10, 42-43.

235 This is the official policy in the United Kingdom, and scholars have found the income shifting result, although wealthier wives are more likely to shift than are wealthier husbands. Melvin Stephens, Jr. \& Jennifer Ward-Batts, The Impact of Separate Taxation on the IntraHousehold Allocation of Assets: Evidence from the UK, 88 J. PuB. Econ. 1989, 2005 (2004). For a discussion of the development of the United Kingdom's policy, see generally Stephanie Hunter McMahon, London Calling, Does the U.K.'s Experience with Individual Taxation Clash with the U.S.'s Expectations?, 55 ST. Louis U. L.J. (forthcoming 2011). Historically, income shifting has not been given tax effect in Canada, although there has been a movement in that direction. The Canadian Supreme Court recently validated an obvious incomeshifting device in which wives were given non-voting interests in family corporations that entitled them to dividends (which were immediately lent back to the corporation and never paid off) as a means of giving these wives taxable income but little else. Maureen Donnelly, Joanne Magee, \& Allister Young, Income Splitting and the New Kiddie Tax: Major Changes for Minor Children, 48 Canadian Tax J. 979, $995-96$ (2000); David G. Duff, Neuman and Beyond: Income Splitting, Tax Avoidance, and Statutory Interpretation in the Supreme Court of Canada, 32 Canadian Bus. L.J. 345, 348-49 (1999); Lisa Philipps, Crackin the Conjugal Myths: What Does it Mean for the Attribution Rules?, 50 Canadian TAx J.1031, 1035-36 (2002). 
say couples are a unit for some purposes but not for others. Deciding when couples are or are not treated as a unit will be left wholly to political caprice.

Individual filing would also require that Congress impose new rules on taxpayers to trace individual ownership within marriage, and the costs of this "attractive complexity" would be borne by many couples who will not benefit economically from individual filing. ${ }^{236}$ All couples would need to maintain records regarding the ownership of property as between spouses so that ownership could be traced, and the tracing proven. Each spouse would need to know (and be able to prove) what portion of joint checking accounts, savings accounts, investments, and even homes he or she owned. This would be difficult, if not impossible, for most taxpayers, and all couples would need to retain such records regardless of whether they engaged in income shifting or materially benefited from individual filing.

Individual filing also imposes a deadweight cost, the cost from which neither the government nor the taxpayer benefits. Revenue measures should benefit either the government or the public because they either raise revenue or encourage socially beneficial behavior by raising less revenue if the behavior is adopted. Individual filing will do neither of these well, but will induce other behavior, tax planning, which is not socially desirable. "[T]ax planning, all tax planning, not just planning associated with traditional notions of shelters, produces nothing of value. ... No new medicines are found, computer chips designed, or homeless housed through tax planning." ${ }^{237}$ As a result, many taxpayers will be worse off as they change their behavior in hopes of winning tax reduction (if their device is recognized) and yet the government will not receive offsetting revenue from their changes.

One might think that individual filing is somehow different, that it is socially valuable because it either encourages wives to enter the paid labor force or for husbands to give property to their wives. Although this might occur at the margins, neither of the benefits will necessarily be gained on a large scale. First, wives do not need to enter the paid labor force for couples to benefit from individual filing because the same tax reduction can be achieved through income shifting. ${ }^{238}$ Second, as shown by pre-1948 planning, for many husbands the goal will be to give wives taxable income with the least amount of control over that income. ${ }^{239}$ Regardless of the devices actually adopted by couples in the U.S., we should assume new and creative means will be devised. Throughout its long past, the Code has not been good at changing social policy

236 For a discussion of the downside of "attractive complexities" in the world of tax, see Steven A. Dean, Attractive Complexity: Tax Deregulation, the Check-the-Box Election, and the Future of Tax Simplification, 34 Hofstra L. Rev. 405, 416-17 (2005).

237 Weisbach, supra note 16, at 222; see also Philip A. Curry, Claire A. Hill \& Francesco Parisi, Creating Failures in the Market for Tax Planning, 26 VA. TAx. Rev. 943, 948 (2007); Daniel N. Shaviro, Economic Substance, Corporate Tax Shelters, and the Compaq Case, 88 TAx Notes 221, 223 (2000).

238 See also supra note 205.

239 For a description of this in the United Kingdom and Canada, see Donnelly, Magee \& Young, supra note 235; Duff, supra note 235; McMahon, supra note 235; Phillips, supra note 235 . Others possibilities would be for wealthy husbands to use these income payments in lieu of alimony in prenuptial agreements or for husbands to give their wives interests in family partnerships with no current distribution rights or control. 
and policymakers should not assume that the tax system can or will change the underlying dynamics within America's families.

That conclusion does not mean that the system should not recognize new forms of American families. Some critics of the joint return legitimately point out that the system unjustly determines which families are permitted, or required, to use the joint return with its attendant burdens and benefits. ${ }^{240}$ In doing so the government willfully ignores these families' abilities to pay taxes. The current system treats cohabitating couples and same-sex couples, even those married under state law, differently. ${ }^{241}$ Because the combined incomes of marital units best reflect their ability to pay taxes, the government should broaden the use of the joint return to include all couples who function as such a unit. For example, couples in state-law-recognized common law marriages have been able to file jointly for a long time. ${ }^{242}$ So, too, should same-sex couples and other couples that choose to enter into civil unions. ${ }^{243}$

The government should not, however, scrap the joint return and ignore all of the problems and inequities that will result because of this current failure to recognize married same-sex couples. ${ }^{244}$ Although the joint return system does not work perfectly for every individual, it is a workable and more just regime than individual filing. Some discrimination will continue; for example, some couples will continue to choose to cohabitate rather than marry for the tax savings and, as a result, distort measurements of their ability to pay taxes. But that will always happen in a free society. No matter what tax unit is chosen, some couples will adjust their private behavior to reduce their collective taxes. ${ }^{245}$ The government should prefer the system that structurally minimizes the amount of avoidance while acknowledging that some relationships do affect relative abilities to pay taxes in the short- and long-term.

Thus, to say that joint tax filing is the most appropriate tax unit for determining how much married couples can pay in federal income taxes does not require that spouses share income or a determination that some family choices are better than others. It merely requires a belief that, relative to other couples, those couples with more income can afford to pay more in taxes, regardless of which spouse earns, controls, and enjoys that money. As Justice Holmes once assumed, regardless of whether spouses are emancipated from each other, the

240 See Cain, Federal Tax Consequences of Civil Unions, supra note 14; Cain, Taxing Families Fairly, supra note 14; Kratzke, supra note 14; Seto, supra note 14; Terry, supra note 14; Ventry, supra note 14.

241 Defense of Marriage Act of 1996, Pub. L. No. 104-199, 110 Stat. 2419 (1996).

242 Rev. Rul. 58-66, 1958-1 C.B. 60-61.

243 Once these couples are justly afforded this treatment, policymakers should be prepared for siblings, parents with children, and others to seek it as well. However, the government does not need to allow every group to file jointly.

244 It is not enough to overrule the IRS's conclusion that Poe v. Seaborn does not apply to same-sex couples. I.R.S. Chief Couns. Mem. 201021050 (May 28, 2010), rev'g I.R.S. Chief Couns. Mem. 200608038 (Feb. 24, 2006). The new ruling does not allow or require these couples to file joint returns. The equitable solution requires Congress to extend the joint return to couples registering under state law. Although some couples will enjoy tax savings, others will lose an opportunity for tax avoidance. Cong. Budget Office, The Potential Budgetary Impact of Recognizing Same-Sex Marriages 1 (2004).

245 Seto argues that the government should treat same-sex couples as "married" to avoid tax avoidance. Seto, supra note 14 , at 1590. 
ownership of wealth by either, if within a marital union, can reasonably be viewed as affecting their collective ability to pay taxes. ${ }^{246}$ If we do not look at this issue as an exploration of taxpayers' ability to pay taxes relative to each other, the government will continue to languish in a political quagmire of marriage bonuses and penalties.

\section{CONClusion}

"To have and to hold" might normally refer to the love of each spouse for the other, but, when taxes are involved, it also includes questions about the most tax-reducing ways to own family property. Before 1948, when one spouse had and held property, it was often shifted to the other spouse to reduce a couple's federal income taxes. Then the 1948 Revenue Act nationalized income splitting for married couples. One major source of interstate and intercouple discrimination in how the federal income tax operated was eliminated. No longer would community property laws or common law tax-avoidance devices work to reduce taxes for some, but not all, married couples. Instead, all couples could use the joint return. ${ }^{247}$

The joint return's history demonstrates that the issue of the tax-filing unit proves to be more difficult once it becomes political. In addition to claims of geographical discrimination between the states, the question of the appropriate tax unit will become conflated with questions of relative tax burdens and whether the tax system should take into account the additional costs of two wage earners versus one. ${ }^{248}$ The latter are primarily concerns of efficiency, not equity, and different people will always be able to make claims for different outcomes. In other words, if Congress changes to a system of individual filing on the grounds that it will induce more wives to work or more couples to marry, new groups will argue that the filing requirement discriminates against them and that it discourages their work effort or marriage decisions. To avoid a repetition of these debates, the tax system should stop looking into people's bedrooms and the government should bring the argument back to its fundamentals. On policy issues, we should refocus on the larger goal of measuring the ability to pay taxes. Married couples reflect that ability vis-à-vis the outside world, regardless of how spouses choose to subdivide their income between themselves.

However, the political value of marriage penalties and marriage bonuses has proven to be too tantalizing to jettison in favor of a discussion about taxpayers' ability to pay taxes. The ability to portray individual filing as neutral to family choices, and joint filing as not, provides valuable political ammunition, even if the proposed individual filing system would be no more neutral among

246 See Hoeper v. Tax Comm'n, 284 U.S. 206, 219-220 (1931).

247 These marriage bonuses, both the one that occurred before 1948, when spouses could use tax-planning devices to shift income, and the other legislated by Congress in 1948, have the effect of reducing the progressiveness of the income tax for wealthy married couples. Nonetheless, these bonuses are not the same; those created after 1948 were generally applicable and the result of the revenue statute rather than individual tax planning.

248 Even if society prefers community property, as seen in the wave of conversion to community property between 1939 and 1947, states adopt as limited statutes as possible. See McMahon, supra note 51, at 589. 
family choices than the system is today. ${ }^{249}$ When the push for individual filing fails, as it has in the past, politicians will again find it an opportunity to advocate a reduction in marriage penalties through rate reductions. ${ }^{250}$ By redirecting the issue to cutting tax rates, which reduces the benefits or burdens of the play between tax brackets, the issue of marriage penalties allows policymakers to subvert the progressivity of the income tax without confronting progression directly. ${ }^{251}$

Not everyone will agree that concern for the progressivity of the income tax or tax avoidance in general should govern the question of the tax unit. Some will continue to support the individual filing system because they believe that the social implications and efficiency gains to be had are more important to society. For them, when Congress has the opportunity it should make decisions that advance what they see as a better, nondiscriminatory treatment of wives. Some might also claim that there is something fundamentally different about marriage today and, because of the increased incidence of divorce, couples are no longer willing to shift income between spouses.

Even if these proponents of individual filing are correct, should the federal government and other taxpayers, such as single taxpayers, low-income couples, and couples with relatively equal incomes, pay in disproportionately higher taxes for these social advances-social advances that might be better made through other systems than the tax system? ${ }^{252}$ Moreover, should the federal income tax allow married couples with firsthand knowledge of their finances to reap economic benefits from their ability to determine who owns, and will be taxed on, what income? Until the fundamental question of property ownership is answered-which is much easier to do in theory than in practice-some couples will always be willing to use "bedchamber transactions" to game the federal income tax system. ${ }^{253}$

249 See supra note 205.

250 See Jane G. Gravelle, The Marriage Tax Penalty 4 (2003). For a sample of how the issue was discussed in 2000, see Ann F. Thomas, Marriage and the Income Tax Yesterday, Today, and Tomorrow: A Primer and Legislative Scorecard, 16 N.Y.L. ScH. J. Hum. RTs. 1, 59 (1999).

251 These rate reductions do nothing to address the existence of the penalty itself, even if they reduce the size of the penalty for any given couple. For many couples, these rate reductions increase their bonuses vis-à-vis single taxpayers. Penalties are only more common for higher income categories. Gravelle, supra note 250, at 32.

252 On the bright side, if Congress does not fix the alternative minimum tax (AMT), there will be less benefit of income shifting because the rate brackets are fewer and less progressive. But the existence of the AMT might nonetheless increase the amount of game-playing because taxpayers will not be sure what strategies will secure them the greatest tax reduction.

253 This phrase was coined by Boris Bittker in 1975. Bittker, supra note 10, at 1394. 